This is the final peer-reviewed accepted manuscript of

Capraro, Luca; Ferretti, Patrizia; Macrì, Patrizia; SCARPONI, DANIELE; Tateo, Fabio; Fornaciari, Eliana; Bellini, Giulia; Dalan, Giorgia: The Valle di Manche section (Calabria, Southern Italy): A high resolution record of the Early-Middle Pleistocene transition (MIS 21-MIS 19) in the Central Mediterranean. QUATERNARY SCIENCE REVIEWS, 165. 0277-3791

DOI: 10.1016/j.quascirev.2017.04.003

The final published version is available online at:

http://dx.doi.org/10.1016/j.quascirev.2017.04.003

Rights / License:

The terms and conditions for the reuse of this version of the manuscript are specified in the publishing policy. For all terms of use and more information see the publisher's website.

This item was downloaded from IRIS Università di Bologna (https://cris.unibo.it/)

When citing, please refer to the published version. 


\title{
The Valle di Manche section (Calabria, Southern Italy): A high resolution record of the Early-Middle Pleistocene transition (MIS 21-MIS 19) in the Central Mediterranean
}

\author{
Luca Capraro $^{\mathrm{a}, \#}$, Patrizia Ferretti ${ }^{\mathrm{b}}$, Patrizia Macri ${ }^{\mathrm{c}}$, Daniele Scarponi ${ }^{\mathrm{d}}$, Fabio Tateo ${ }^{\mathrm{e}}$, Eliana Fornaciari ${ }^{\mathrm{a}}$, \\ Giulia Bellini $^{\text {a }}$, Giorgia Dalan ${ }^{\mathrm{a}}$ \\ a Dipartimento di Geoscienze, University of Padova, Via G. Gradenigo 6, I-35131 Padova, Italy \\ ${ }^{\text {b } C N R-I D P A}$, Via Torino 155, I-30172, Venezia Mestre, Italy \\ c Istituto Nazionale di Geofisica e Vulcanologia, Via di Vigna Murata 605, I-00143 Roma, Italy \\ d Dipartimento di Scienze Biologiche, Geologiche e Ambientali, University of Bologna, Via Selmi 3, I-40126 Bologna, Italy \\ e CNR-IGG, Via G. Gradenigo 6, I-35131 Padova, Italy
}

Keywords:

MIS 19Matuyama-Brunhes boundary; Southern ItalyCrotone BasinGSSPChronostratigraphy

\begin{abstract}
The on-land marine Valle di Manche section (Crotone Basin, Calabria, Southern Italy), one of the candidates to host the GSSP of the Middle Pleistocene ("Ionian") Stage, preserves a manifold record of independent chronological, paleoclimatic and stratigraphic proxies that permit a straightforward correlation with marine and terrestrial reference records at the global scale. In particular, the section holds an excellent record of the Matuyama-Brunhes magnetic reversal, which occurs in the midst of Marine Isotope Stage (MIS) 19. We report on a complete revision of the section that improves dramatically the available dataset, especially in the stratigraphic interval straddling the Lower-Middle Pleistocene boundary. Our benthic $\delta^{18} \mathrm{O}$ record provides evidence that the Matuyama-Brunhes transition, the stratigraphic position of which is marked by a prominent tephra (the "Pitagora ash"), occurred during full MIS 19, in agreement with many records worldwide. We obtained an age of $786.9 \pm 5 \mathrm{ka}$ for the Matuyama-Brunhes magnetic reversal and pinpointed the paleomagnetic transition of to a $3 \mathrm{~cm}$-thick interval, indicating that the event was very fast. Since the section fulfills all the requirements to host the GSSP of the Ionian Stage, we propose that the boundary should be placed at the base of the "Pitagora ash", ca. $12.5 \mathrm{~cm}$ below the midpoint of the Matuyama-Brunhes reversal.
\end{abstract}

\section{Introduction}

The definition of Global Stratotype Sections and Points (GSSPs) is one of the main tasks to be accomplished by the Earth scientists' community. The recognition of formal boundaries and chronostratigraphic units represents a fundamental step towards a common language in stratigraphy, which is of the essence for future work.

So far, the Pleistocene Series is subdivided into four4 Stages, only two of which (Gelasian and Calabrian, Lower Pleistocene) have been formally defined (Rio et al., 1998; C ita et al., 2012). The "Ionian" and "Tarentian" Stages (Middle and Upper Pleistocene, respectively) are employed informally, though their formal definition is expected shortly.

In keeping with all Pliocene and Pleistocene Stages, there is a broad agreement to define the GSSP of the Ionian Stage in correspondence to a geomagnetic reversal, namely the Matuyama-Brunhes (M-B) boundary,in mid-MIS 19 (Richmond, 1996; Pillans, 2003; Head et al., 2008; Pillans and Gibbard, 2012). Unfortunately, the M-B boundary is usually poorly documented in the marine on-land record (see Singer, 2014). To our knowledge, the only available marine on-land

Corresponding author

Email address luca.capraro@unipd.it (L. Capraro) record of the M-B reversal in the Mediterranean area is that of the Valle di Manche section (VdM hereafter), located in the Crotone sedimentary basin (Calabria, Southern Italy).

The VdM section has been investigated since the early 1990s (Rio et al., 1996). However, the amount and resolution of the data published so far is nowadays inadequate, considering the recent trend towards high-resolution studies. We recently undertook a complete revision of the local succession in order to obtain a more detailed and complete information on the VdM section, with the aim of supporting a formal proposal to define the GSSP of the Ionian Stage (Cita et al., 2006). Based on the new data, we can demonstrate that the VdM section holds all the key requirements for the definition of a GSSP, as per the recommendations of Remane et al. (1996). Given that all GSSPs of the Pliocene and Pleistocene Series ratified so far are located in Southern Italy (Crotone Basin and Sicily), defining the GSSP of the Ionian Stage in the VdM section would also abide by a basic principle of regional and historical continuity, with understandable benefits such as high correlation potential, comparable depositional settings and proxies, simple logistics, etc.

\section{Geologic setting}

The studied section belongs to the late Neogene to Quaternary Crotone sedimentary Basin (CB hereafter), located in the central- 
eastern part of the Calabria region, Southern Italy (Fig. 1a). The CB is generally interpreted as a forearc basin located above the internal part of the Calabrian accretionary wedge (Rossi and Sartori, 1981; Barone et al., 1982; Van Dijk and Okkes, 1991). It is bounded by two major NW-SE left-lateral shear zones, these being the Rossano-San Nicola to the north and the Petilia-San Sosti to the south (Fig. 1b), yielding local block rotation (Speranza et al., 2011; Macrì et al., 2014). The CB consists of a series of half-grabens that host a very thick $(>3000 \mathrm{~m})$ and well-exposed upper Miocene to Pleistocene sedimentary succession, where vastly different facies, ranging from offshore marly clays to continental (fluvial) gravels, are preserved. Roda (1964) subdivided the sedimentary succession of the CB into three main tectono-stratigraphic sequences bounded by major unconformities, each representing a major event of deformation and basin reorganization. The first sequence encompasses the Serravallian to early Messinian interval, while the second developed from middle Messinian to Early Pliocene; the third extends from the Middle Pliocene (Piacenzian) to the Middle Pleistocene (Capraro et al., 2006; Macrì et al., 2014). The latter sequence was initiated by a rapid and massive increase in the regional subsidence rates, which attained to a maximum during the Early Pleistocene. This event is marked by the widespread deposition of a thick succession of monotonous, marine muddy slope deposits ("Cutro 1" of Rio et al., 1996; lower part of the "Cutro Marly Clays" of Roda, 1964). In a large part of the CB, the regional uplift begun during, or immediately after, the deposition of the "Cutro 1". This pattern is well documented in sections exposed along the modern coast, such as Vrica and Le Castella (Pasini et al., 1975; Pasini and Selli, 1977), where the Pliocene "Cutro 1" marls are unconformably overlain by middle-late Pleistocene marine terraces (Massari et al., 2010). In small internal sectors of the CB, such as the San Mauro area (Fig. 1b and c), higher tectonic subsidence rates promoted the activity of synsedimentary faults. These sectors developed as confined sub-basins, where the sedimentation of marine cyclothemic successions lasted well into to the Middle Pleistocene, with deposition of manifold sedimentary facies and architectural stacking patterns (Massari et al., 2010; Capraro et al., 2011). Immediately on top of the "Cutro 1", which is truncated by a major late Early Pleistocene unconformity (upper "large" Gephyrocapsa Zone: Rio et al., 1990), rests the "Cutro 2" (upper part of the "Cutro Marly Clays" of Roda, 1964). The "Cutro 2", which correlates grossly with the "small" Gephyrocapsa Zone (Rio et al., 1990), is represented by a wide range of sedimentary facies, pointing to depositional settings ranging from outer to inner shelf (Massari et al., 2002). In proximal settings, such as the San Mauro area, it consists of four cyclothems bounded by minor unconformity surfaces (Rio et al., 1996).

\subsection{The San Mauro sub-basin}

The San Mauro sub-basin is located in the internal part of the Crotone Basin (Fig. 1b). It is bounded by two northeast-trending dextral oblique-slip faults (Rio et al., 1996; Massari et al., 1999) that became active during the Early Pleistocene (Massari et al., 2002) and promoted the growth of a synsedimentary syncline, where a shallowing-upward, marine to continental succession was laid (the "San Mauro Sandstone" of Rio et al., 1996; SMS hereafter).

The bedrock of the local sedimentary succession (Fig. 2) is represented by the "Cutro 2" unit. The latter is truncated just above the base of the Pseudoemiliania lacunosa Zone (Base of Gephyrocapsa sp.3 sensu Rio, 1982, calibrated with MIS 25 in the Central Mediterranean; Castradori, 1993; Raffi et al., 2006) by a major erosional surface that predates the deposition of the cyclothemic SMS. With respect to the underlying "Cutro" mudstones, the SMS shows a distinct change in sedimentation style, with facies associations and thicknesses that change rapidly over short distances in response to synsedimentary faulting and folding (Massari et al., 2002; Capraro et al., 2011). The SMS is composed of a stack of transgressive/regressive (T/R) cycles (Rio et al., 1996) that mainly reflect the local sedimentary response to eustasy and local sediment supply. However, the lo-

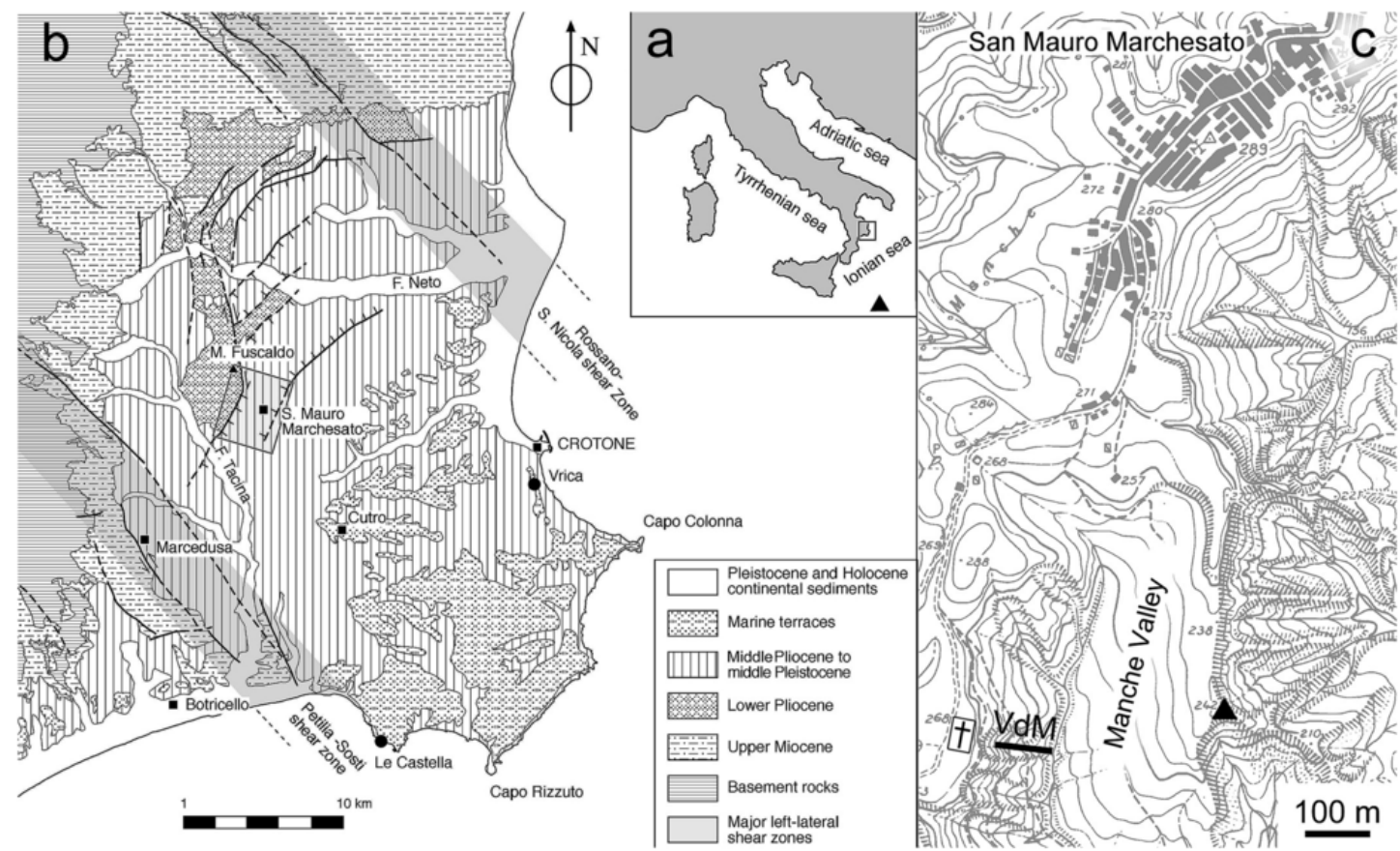

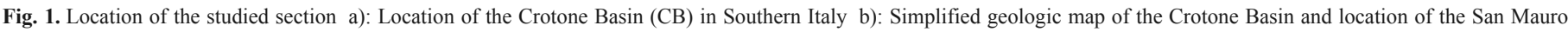

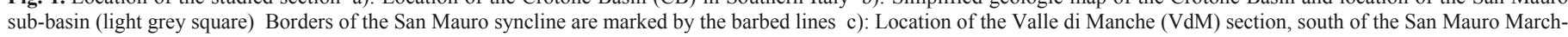
esato village 

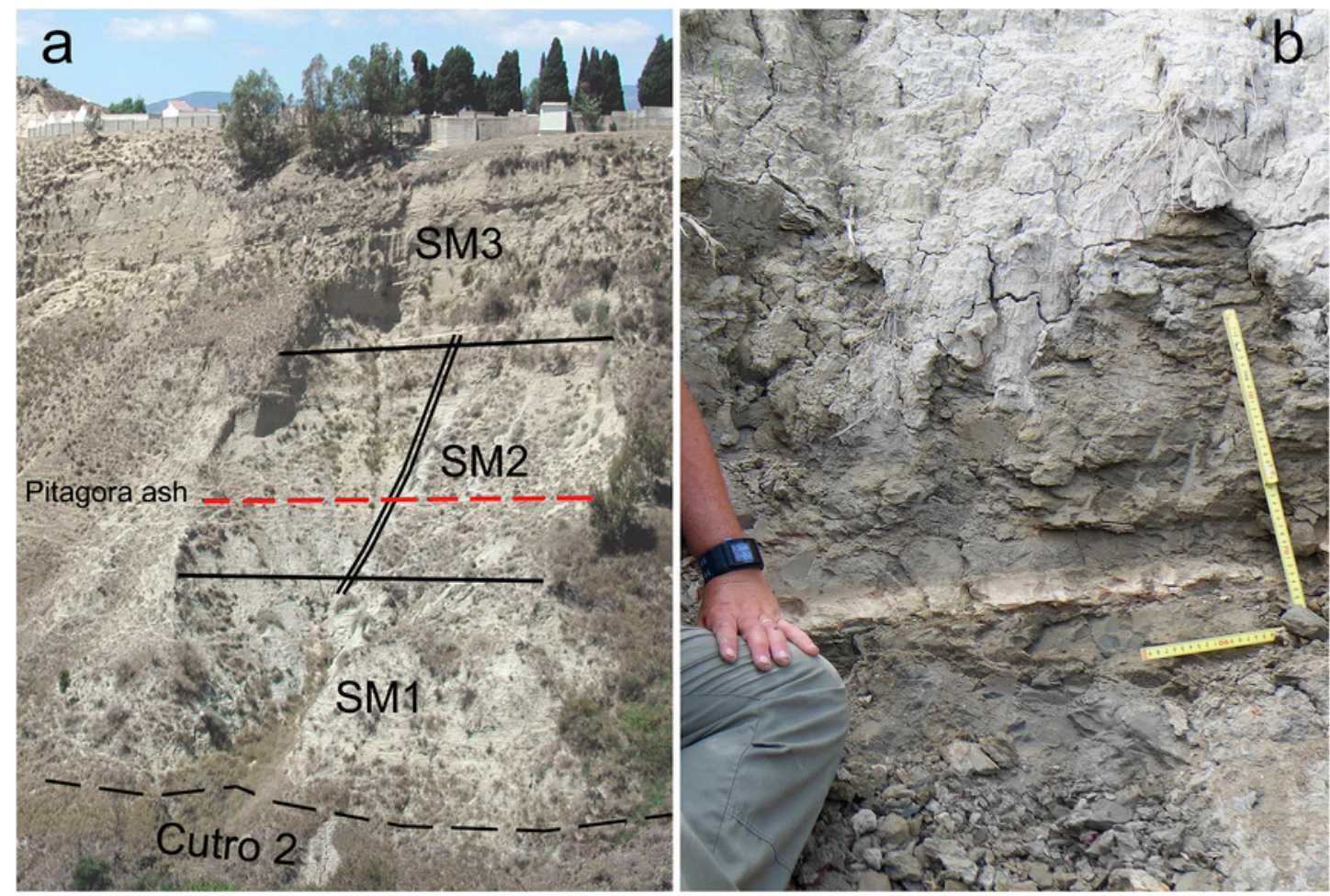

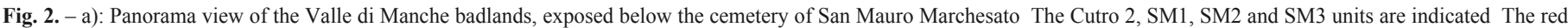

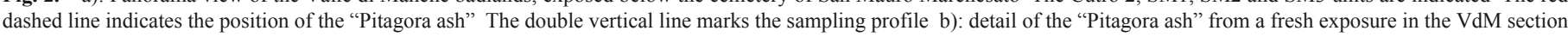
(photo by M Head) (For interpretation of the references to colour in this figure legend, the reader is referred to the web version of this article )

cal subsidence rates play a key role in shaping the stratigraphic succession of the San Mauro sub-basin (Rio et al., 1996; Massari et al., 2002, 2007). Rio et al. (1996) subdivided the SMS into three component units (SM1 to SM3) that can be traced virtually basinwide in the San Mauro area (Fig. 3).

The basal SM1 unit rests unconformably on top of the "Cutro 2" marly clays. It consists of a distinctive prograding package of shallow-water, coarse-grained sands that attain to a maximum thickness of ca. $45 \mathrm{~m}$ in depocentral areas (Massari et al., 2002). Shells of the boreal guest Arctica islandica are locally common. The micropaleontological content is distinctively poor, being represented by reworked calcareous microfossils and shallow-water benthic foraminifers (Rio et al., 1996). Scarponi et al. (2014) inferred a paleodepth of ca. $30-40 \mathrm{~m}$ for this interval, which was correlated to the Marine Isotope Stages (MIS) 24-22 glaciation by Capraro et al. (2005).

The SM2 unit, ca. 5-40 m thick, is represented by a prominent grayish package of soft outer-to mid-shelf deposits, ranging from silty muds to sandy silts. Stratal geometries and thicknesses (Massari et al., $2002,2007,2010)$ point to a significant deepening and increase of the local tectonic subsidence rates at the end of the MIS 24/22 glaciation, which emphasized dramatically the effects of glacioeustasy (Capraro et al., 2005). The strong tectonic subsidence promoted the continuous creation of accommodation space and deposition of a continuous and expanded record of the interval from late MIS 22 to early MIS 18 (Capraro et al., 2005). Embedded in the upper muddy interval of SM2 (in MIS 19) is a volcaniclastic layer (the "Pitagora ash" of Rio et al., 1996).

The silty interval at the top of SM2 marks the beginning of a major regressive trend, which culminates in the sandy shoreface and fluvial deposits of SM3 (Fig. 2). The latter attains a total thickness of $40 \mathrm{~m}$ in the marginal sectors and ca. $120 \mathrm{~m}$ in depocentral areas. It consists of a progradational stacking pattern of cycles that incorpo- rate upward-increasing amounts of marginal marine and fluvial deposits. In particular, the basal part of the SM3 is represented by a siciliclastic prograding shallow-water sandy body with a shingled internal architecture, locally very rich in macrofossils. Above is an alternation between fluvial gravels, sands and lagoonal muds that document the youngest infill of the San Mauro sub-basin (i.e., post-MIS 18) prior to the uplift of the area (late Middle Pleistocene; Capraro et al., 2011).

\subsection{The section}

The Valle di Manche (VdM) section is well exposed along the northwestern flank of the Manche valley, just below the cemetery of the village of San Mauro Marchesato (Figg. 1c, 2a). The VdM profile was first described by Roda (1964) and then designated by Di Grande (1967) as the type area of the "Molassa di San Mauro" Formation. Later, Rio et al. (1996) utilized the VdM section as the pivotal component for reconstructing the stratigraphic architecture of the San Mauro sub-basin. Therefore, the Manche valley badlands possibly host the longer-lasting outcrops in the whole $\mathrm{CB}$, being exposed uninterruptedly since the 1960s. The VdM section preserves the best available record of the SMS, because it was laid in a depocentral setting of the San Mauro sub-basin where, in contrast with the marginal (landward) areas, transgressive-regressive cycles are separated by conformable surfaces and the stratigraphic record is complete (Rio et al., 1996; Capraro et al., 2005; Massari et al., 2002, 2007).

Ideally, the VdM section extends from the top of the "Cutro 2" marly clays to the base of the upper (continental) part of the SM3 sandstones. At VdM, the uppermost "Cutro 2" is nowadays exposed poorly because of the thick vegetation. However, the "Cutro 2"/SMS boundary is well represented in the more marginal sectors of the San Mauro sub-basin (Rio et al., 1996; Massari et al., 2002). 


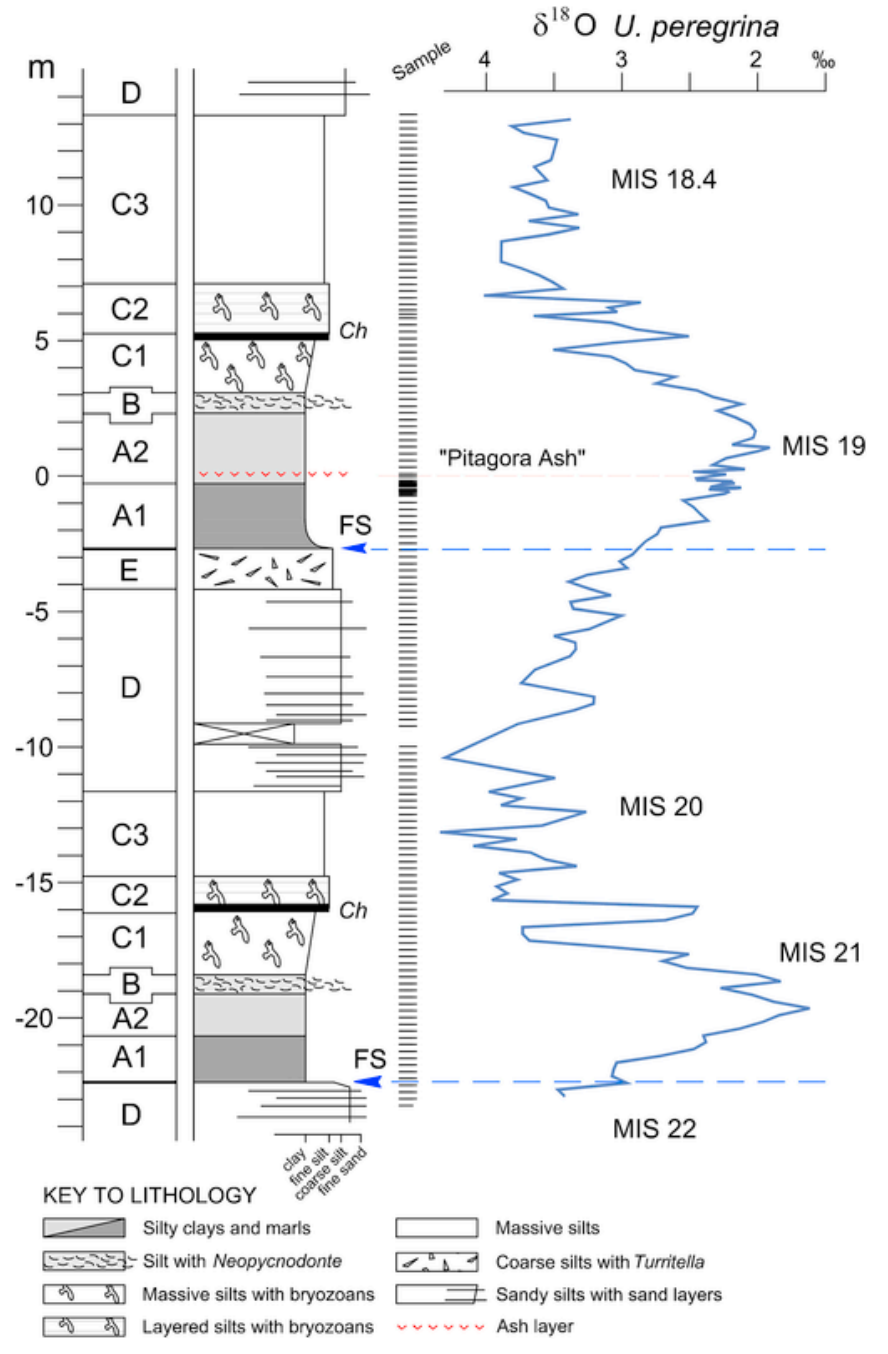

Fig. 3. Physical stratigraphy and $\delta^{18} \mathrm{O}$ stratigraphy for Uvigerina peregrina at Valle di Manche FS: major flooding surfaces $C h$ : dark layers very rich in Chondrites, indicative of a poorly oxygenated environment (Bromley and Ekdale, 1984) See Table 1 for facies description

We focused our investigation on the shelf muds of the SM2 unit, which crop out conveniently and are very easy to describe and sample. This interval contains the record of the last geomagnetic reversal, i.e. the Matuyama-Brunhes boundary (MIS 19).

The reconstructed stratigraphic log (Fig. 3) shows a closely spaced, yet consistent, alternation of facies (see Table 1 for a description). We insist that, within the interval of relevance, all facies changes are subtle and gradual, and no evidence occurs of erosional surfaces, hiatuses, abrupt variations in sediment composition and/or changes in the sedimentation style, which is persistently dominated by mud settling (Massari et al., 2002, 2007; Scarponi et al., 2014). We emphasized graphically any lithological contrast, change in sedimentation style and facies boundary only in order to stress the well-developed stratigraphic architecture of the section.

In the SM2 interval, the estimated depositional settings range from middle shelf to outer shelf/upper slope. We interpreted the bottom of the clayey intervals (facies A1; Table 1) in MIS 21 and MIS 19 as major flooding surfaces (FS in Fig. 3) that, according to the approach of Massari et al. (2007), mark the base of two transgressive-regressive $(T / R)$ cycles with similar internal organization of facies, especially in the fine-grained intervals (Fig. 3). The persistence of
Table 1

Description of the facies recognized in the Valle di Manche section and employed in Fig 3

Facies Description

E An individual layer, ca $40 \mathrm{~cm}$-thick, of medium to coarse silts and fine sands with a loosely packed concentration of the gastropod Turritella tricarinata, locally associated with sparse pectinids Benthic foraminiferal assemblages are similar to those of facies C3 The inferred environment is a prodelta (mid-shelf) setting subjected to high sedimentation rates, possibly under the influence of riverine waters (Huntley and Scarponi, 2012)

D Massive, fine to coarse silts alternating with sharp-based, planar-laminated, generally thin-bedded tabular to lenticular layers of fine micaceous sands (sand/mud ratio between 1/10 and 1/5) Stringers of vegetal debris and plant macrorests are extremely abundant Restricted to the upper part of the SM1 unit, sparse shells of Arctica islandica are also present Benthic foraminiferal assemblages are similar to those of facies C3 The depositional setting is a distal to intermediate delta-front, where a background sedimentation sustained by mud settling was punctuated by the emplacement of thin sandy layers in response to high-energy events, such as river floods and/or storm-induced flows

C3 Massive silts with dispersed autochthonous skeletal material (mainly mollusks) and sparse vegetal remains that increase in abundance upwards The benthic foraminiferal fauna is dominated by Cassidulina spp and Elphidium spp associated with Bulimina marginata and Bolivina catanensis The occurrence of shells in life position suggests a low-energy environment with frequent mud blanketing in a mid-shelf environment, grading upwards to a prodelta setting

C2 Couplets of alternating light, skeletal-rich layers of overcompacted coarse silts and dark, poorly fossiliferous layers of soft muds The thickness of individual strata is ca $20 \mathrm{~cm}$ The base of this unit is marked by a distinctive, $\sim 10 \mathrm{~cm}$-thick blackish layer rich in Chondrites (Ch in Fig 2) that points to short-lived episode of reduced oxygenation at the bottom (Bromley and Ekdale, 1984)

C1 Massive, unconsolidated muddy silts very rich in bryozoans and unsorted skeletal material, indicative of intense in situ macrofaunal fragmentation The benthic foraminiferal assemblage is dominated by Cassidulina laevigata; epiphytic forms increase in abundance upwards, suggesting a gradual transition from an outer to a mid-shelf setting

B Detritic firmgrounds mantled by biogenic concentrations of the gregarious deep-sea ostreid Neopycnodonte cochlear Shells are embedded in a matrix of clayey silts, pointing to conditions of minimum sediment accumulation rates (starvation) in an outer shelf-upper slope setting (Scarponi et al, 2014)

A2 Grey, massive silty clays grading upwards to clayey silts Fossils are increasingly common, pointing to an improved oxygenation at the sea floor with respect to the underlying A1 unit The benthic foraminifer assemblage is rich, with dominant Uvigerina peregrina

A1 Muddy silts rapidly grading upwards into dark, massive muds Large dispersed burrows and sulphide nodules are present This facies is indicative of fine-grained substrates in an outer shelf setting, with high fluxes of organic matter and poor oxygenation at the seafloor The benthic foraminifer fauna is scanty and oligospecific, with Uvigerina peregrina, Brizalina spp and Bulimina marginata The mollusk fauna is very scarce (Scarponi et al ,2014) and mainly represented by a juvenile assemblage dominated by Corbula gibba, indicative of hypoxic conditions (Ceregato et al , 2007) and/or high sediment accumulation rates (Scarponi and Angeletti, 2008)

similar depositional conditions during each $\mathrm{T} / \mathrm{R}$ cycle suggests that the main traits of the $\mathrm{VdM}$ succession were primarily shaped by glacioeustasy, although during the deposition of the SM2 unit a strong local subsidence promoted the continuous creation of accommodation space and the persistence of open marine conditions also in correspondence to the eustatic sea-level minima.

\subsection{The "Pitagora ash"}

The "Pitagora ash" (Fig. 2b) is an indurated, spongy and very light layer that contains a substantial volcaniclastic fraction made of fine-grained glass shards and magmatic crystals. Its color ranges from off-white to pinkish, depending on the weathering. Thickness is highly variable, ranging from ca. $3-4 \mathrm{~cm}$ in marginal settings to ca. 
$30 \mathrm{~cm}$ in depocentral areas, where the volcaniclastic fraction is largely subordinate to a terrigenous (detrital) muddy fraction (Rio et al., 1996); small variations are also observed at the outcrop scale.

The optical microscopy study of the "Pitagora ash" reveals an abundance of both volcanic clasts (mainly glass shards and feldspars) and non-volcanic components (quartz, epidotes, chlorites and white micas). According to the classification scheme of Le Maitre (2002), it can be identified as a tuffite. The fine-grained detrital fraction is generally dispersed, albeit clay chips with iron oxides are present. X-ray diffraction (XRD) analyses of the bulk rock match the optical observation and also demonstrate the presence of zeolites (phillipsite), which are more abundant within the silt-clay fraction $(<63 \mu \mathrm{m})$. According to the TAS (Total Alkali versus Silica) classification, chemistry of the glass shards by means of SEM-EDS investigation (see Gasparotto et al., 2000 for methodological details) points to a phonolitic composition, with a small dispersion of data points toward the trachyte field (Fig. 4). Regrettably, only few sanidine crystals were available for the analysis (mole \% Or: 74,61; Ab: 23,36; An: 3,3). So far, the scarcity of well-preserved sanidine crystals and the very fine grain of the volcaniclastic fraction of the "Pitagora ash" at VdM hampered our attempts to achieve a radiometric age.

Being hosted in dark, soft, massive muds, the "Pitagora ash" is prominent and very easy to detect in the field (Fig. 2b). It can be traced basinwide, representing the most practical and reliable tool for long-distance correlations within the San Mauro area (Rio et al., 1996). In particular, only the "Pitagora ash" can provide unambiguous physical linkage between depocentral sections, where the stratigraphic architecture is basically represented by a mere vertical stack of $\mathrm{T} / \mathrm{R}$ cycles, and marginal areas, where sedimentary bodies are often amalgamated and truncations, omission surfaces and facies changes are widespread (Massari et al., 2002, 2007). Still, its usefulness as physical reference for defining the GSSP of the Ionian Stage may prompt criticism, because the sedimentary mechanisms that originated the "Pitagora ash" are uncertain.

Capraro et al. (2015) tentatively described the "Pitagora ash" as a "resedimented" layer, because it preserves small-scale sedimentary structures, such as plane-parallel lamination and convolutions (Massari et al., 2007), and the absence of a basal massive $T_{\mathrm{a}}$ interval is consistent with a low-density turbidity current (sensu Lowe, 1982).

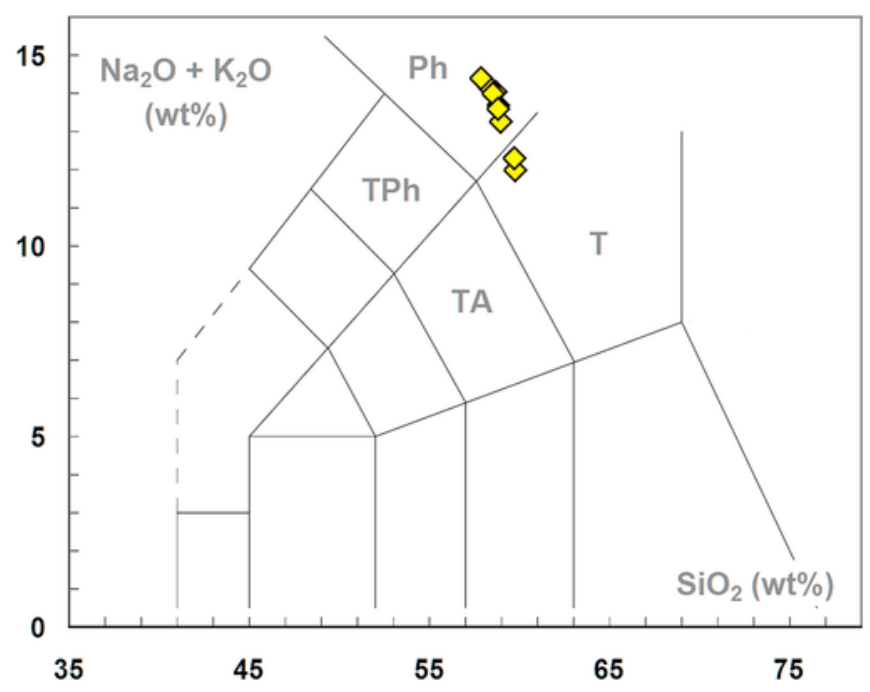

Fig. 4. TAS classification diagram (Le Maitre, 2002) of glass shards from the "Pitagora ash" (dry basis) $\mathrm{Ph}$ : phonolite, T: trachite, TA: trachyandesite; TPh: tephriphonolite
However, the presence of sedimentary structures is not sufficient to determine whether it represents a "primary" tephra or a product of resedimentation of older volcaniclastic material (Mezzetti et al., 1991; Manville and Wilson, 2004; Manville et al., 2009). Indeed, discriminating between "primary" tephra layers, generated from ash falling and settling, and "secondary" deposits, originated from the resettling of older volcaniclastic material, is generally not possible (Carey and Sigurdsson, 1978; Sparks et al., 1983; Manville and Wilson, 2004).

In an open marine setting, the deposition and preservation of thick layers of fine-grained volcaniclastic materials can hardly be interpreted as the response to pure ash fall and settling (Huang, 1980). In a pure settling regime, ash particles would sink over months to decades, and bioturbation would immediately mix the slowly accumulating volcaniclastics with the undifferentiated host sediments (Manville and Wilson, 2004). However, tephra layers are usually characterized by a sharp base, implying a massive and abrupt suppression of the benthic fauna, and a bioturbated top, in response to the subsequent recolonization of the sea floor (Cita and Podenzani, 1980; Marquez, 2000), demonstrating that the sedimentation process was extremely fast.

At VdM, the "Pitagora ash" is the sole evidence consistent with a sedimentary process other than mud settling in the whole SM2 interval, where the fine fraction originated from fallout (Massari et al., $2002,2007)$ as reasonably expected in any sedimentary succession accumulated below the storm wave base (Clifton, 2006). Indeed, macrofossils do not show evidence of preferred orientation, lags or reworking in the whole SM2 unit (Scarponi et al., 2014). Anyhow, even in the case that the "Pitagora ash" was emplaced by a low-density turbidity current, its erosive potential was arguably very weak, with negligible effects on the stratigraphic continuity given the overall high sediment accumulation rates.

Reasonably, preservation of the "Pitagora ash" in the San Mauro sub-basin was possible because whitish volcaniclastic material was deposited within the dark, hypoxic and hardly bioturbated muds of MIS 19 (Fig. 2b), where sediment mixing was extremely weak. In well-oxygenated settings, such as the neighboring Marcedusa sub-basin (Capraro et al., 2011), the correlative tephra layer was probably destroyed.

The coeval Montalbano Jonico and Chiba sections (Ciaranfi et al., 2010; Kazaoka et al., 2015) are characterized by much higher sediment accumulation rates than VdM, which further challenge the preservation potential of volcaniclastic ashes as individual layers (Manville and Wilson, 2004). However, these sections host numerous distinctive tephra layers (Petrosino et al., 2015; Kazaoka et al., 2015). This paradox can be explained by the evidence that both Montalbano Jonico and Chiba (Ciaranfi et al., 2010; Kazaoka et al., 2015; Simon et al., 2016) were affected by a pervasive regime of event sedimentation (sensu Wheatcroft, 1990; Bentley et al., 2006), which would have favored the rapid and massive accumulation of fine volcaniclastic material in the form of turbidity currents.

\section{Materials and methods}

We pinpointed the sharp base of "Pitagora ash" as the zero-elevation surface (Fig. 3). One meter at a time, we removed the regolith in order to expose a fresh flat surface of the bedrock and, after describing the physical stratigraphy, we picked blocks of ca. $300 \mathrm{~g}$ of sediment at a regular stratigraphic distance of $25 \mathrm{~cm}$.

Exceptions were made in the layered silty unit, where we picked a sample from any individual stratum (ca. $20 \mathrm{~cm} / \mathrm{sample}$ ). Following the results of Rio et al. (1996), in the interval straddling the "Pitagora 
ash" we sampled at very high resolution (up to ca. $2 \mathrm{~cm}$ ) for magnetostratigraphic investigation; some of these samples were also used for stable isotope analyses (Table 2).

In the well-exposed interval above the "Pitagora ash" (SMA samples; Fig. 3), we extended our investigation up to ca. $13.5 \mathrm{~m}$ level (sample SMA 56; Fig. 3), at the bottom of the sandy SM3 unit (Rio et al., 1996; Capraro et al., 2005). Below the "Pitagora ash", we followed the same trajectory as above for a stratigraphic distance of ca. 3 m (samples SMA-1 to SMA-14 in Fig. 3), where a small patch of vegetation forced us to move horizontally by ca. $2.5 \mathrm{~m}$ and to proceed along a contiguous profile (samples SMB1 to SMB 76). Relocation was safe, because we exploited the marker bed rich in Turritella tricarinata that can be traced easily across the VdM badland. We halted our investigation at the $-23.25 \mathrm{~m}$ level, at the top of the shallow-water SM1 sands (late MIS 22; Fig. 3). Altogether, the sampled interval is ca. $37 \mathrm{~m}$ thick. Samples (Table 2) were dispatched to the Department of Geosciences of the University of Padova, where they were dried, weighed and split into smaller portions to be analyzed. The remains were sealed into small plastic bags and stored in the Department's warehouse for future use and reference. A comprehensive checklist of the analyzed samples is presented in Table 2 .

For stable isotope analyses, we processed 143 samples (Table 2). $100 \mathrm{~g}$ of sediment were washed on a $63-\mu \mathrm{m}$ sieve using distilled water and oven-dried overnight on the sieves at $50{ }^{\circ} \mathrm{C}$. From the fraction $>150 \mu \mathrm{m}$ we handpicked pristine specimens of Uvigerina peregrina, which occur continuously throughout the interval analyzed in this study. Between 10 and 15 specimens were employed for each isotopic analysis. Tests were crushed gently under the microscope using two clean glass plates, transferred to the mass-spectrometer vials and soaked in $3 \%$ hydrogen peroxide, in order to remove any possible organic contaminant. Analytical grade acetone was then added and samples were cleaned ultrasonically, after which the excess liquid was siphoned off. Samples were finally oven-dried overnight at $50{ }^{\circ} \mathrm{C}$ before the analysis. Carbon dioxide for isotopic analysis was released using orthophosphoric acid at $70{ }^{\circ} \mathrm{C}$ in an automated continuous flow carbonate preparation GasBench II device, and analyzed in a Thermo Scientific Delta V Advantage Isotope Ratio Mass Spectrometer at the Department of Geosciences of the University of Padova. The laboratory standard (Carrara marble MAQ1) was calibrated to VPDB through NBS 19 , using the values of $-2.20 \%$ for the $\delta^{18} \mathrm{O}$ and $+1.95 \%$ for the $\delta^{13} \mathrm{C}$, as recommended by Coplen $(1988,1994)$. Analytical reproducibility (as indicated by the MAQ1 analyses) was $\pm 0.09 \%(1 \sigma)$.

For the analysis of calcareous nannofossil assemblages, we investigated 74 samples in the interval between MIS 21 and the MIS 19-MIS 18 transition (Table 2). For each sample, a small fragment of dry sediment was cleaned and ground onto a cover slip, moistened with a drop of distilled water and smeared across the cover slip with a wooden toothpick. The cover slip was then glued to a slide using Norland optical adhesive and cured under U.V. light.

Palynological analyses were performed on 46 samples in the interval between -3.75 and $+7.06 \mathrm{~m}$ (MIS 19; Table 2). $10 \mathrm{~g}$ of clean, oven-dried sediment were treated following the standard techniques $(\mathrm{HCl}, \mathrm{HF}$, gravitative separation via heavy liquids, ultrasound treatment) modified according to our internal lab procedures. Samples were mounted on disposable slides by means of glycerin jelly, and observed at the optical microscope with a maximum magnification of $640 \times$. In order to achieve a statistically reliable information, a minimum of 100 pollen grains (Pinus excluded) were counted for each sample. Concentration, preservation and diversity of the pollen assemblages can be deemed good for a Pleistocene marine succession.
For magnetostratigraphic investigations, we collected 84 in situ oriented samples in the stratigraphic interval between $-24.80 \mathrm{~m}$ and $+6.16 \mathrm{~m}$ (Table 2), focusing our attention on the interval encompassing the "Pitagora ash". Samples were either hand-picked or drilled using a petrol-powered portable drill and oriented before extraction by means of a magnetic compass corrected to account for the current mean magnetic declination of the local geomagnetic field ( $\mathrm{ca}+2^{\circ}$ ac-cording to Istituto Nazionale di Geofisica e Vulcanologia, 2007). Measurements were performed at the paleomagnetic laboratory of the Istituto Nazionale di Geofisica e Vulcanologia in Rome and the natural remanent magnetization of all specimens was measured in a magnetically shielded room with a DC-SQUID cryogenic magnetometer (2G Enterprises, USA).

\section{Results}

\subsection{Stable oxygen isotopes}

We have reconstructed a continuous $\delta^{18} \mathrm{O}$ stratigraphy for the infaunal benthic foraminiferal species Uvigerina peregrina (Fig. 3), which has long been demonstrated to precipitate its calcite in oxygen isotopic equilibrium with respect to seawater (Shackleton, 1974). The $\delta^{18} \mathrm{O}$ of this species represents an excellent practical tool for correlation to the open marine records at a global extent, as it holds a strong glacioeustatic component during the time interval considered in this study (Shackleton, 1974; Elderfield et al., 2012). To our knowledge, the $\mathrm{VdM}$ record is the only continuous $\delta^{18} \mathrm{O}$ data set of $U$. peregrina reconstructed so far for the interval included between MIS 22 and 18 in the Mediterranean basin.

The benthic $\delta^{18} \mathrm{O}$ values range from 1.62 to $4.34 \%$ vs. VPDB (Fig. 3 ). The "lightest" (interglacial) values are in good agreement with the isotopic compositions of modern Uvigerina spp. in the eastern Mediterranean basin, which range from $1.80 \%$ in the Sicilian Strait to $2.20 \%$ in the Levantine Sea (Vergnaud-Grazzini et al., 1986). Likewise, "heavier" (glacial) values compare well to those calculated for Uvigerina spp. from various water masses during the Last Glacial Maximum (4.9\%o-4.25\%; Vergnaud-Grazzini et al., 1986). This correspondence is positively surprising, because it is usually assumed that the isotopic signal in a shelf setting may be heavily disturbed by local factors, such as temperatures and river runoff, and not correlate to the open marine records.

A simple visual correlation of our $\delta^{18} \mathrm{O}$ stratigraphy to open marine reference records (e.g., Lourens, 2004; Lisiecki and Raymo, 2005; Konijnendijk et al., 2015) confirms that the studied interval spans continuously from the termination of MIS 22 to full MIS 18.4. Regrettably, in spite of the increased sampling resolution with respect to that available in Capraro et al. (2005), information is still probably poor in the condensed interval corresponding to MIS 21.

\subsection{Paleodepth}

According to Scarponi et al. (2014), the local paleodepths varied from ca. $60-150 \mathrm{~m}$ with a minimum of ca. $25-30 \mathrm{~m}$ in the SM1 unit (MIS 24/22), which was not investigated for this work.

Being a sound proxy of the global sea-level (Shackleton, 1967), the $\delta^{18} \mathrm{O}$ record of $U$. peregrina represents a benchmark for testing the paleodepth curve reconstructed by Scarponi et al. (2014) based on the fossil mollusk fauna. The correlation is excellent (Fig. 5) and provides independent verification that, in spite of the shelfal setting, the $\delta^{18} \mathrm{O}$ record of $U$. peregrina essentially preserves a glacioeustatic component. 
Table 2

Checklist of the analyses performed for this study

\begin{tabular}{|c|c|c|c|c|c|}
\hline Sample & Level (m) & Calcareous nannofossils & Pollen & $\delta^{18} \mathrm{O} \delta^{18} \mathrm{O} \delta^{18} \mathrm{O} \delta^{18} \mathrm{O} \delta^{18} \mathrm{O} \delta^{18} \mathrm{O} \delta^{18} \mathrm{O}$ & Magneto \\
\hline SMA55 & 1331 & & & - & \\
\hline SMA54 & 1306 & - & & • & \\
\hline SMA53 & 1281 & & & - & \\
\hline SMA52 & 1256 & - & & - & \\
\hline SMA50 & 1206 & - & & & \\
\hline SMA49 & 1181 & & & - & \\
\hline SMA48 & 1156 & - & & - & \\
\hline SMA47 & 1131 & & & & \\
\hline SMA46 & 1106 & - & & - & \\
\hline SMA45 & 1081 & & & - & \\
\hline SMA44 & 1056 & - & & • & \\
\hline SMA43 & 1031 & & & - & \\
\hline SMA42 & 1006 & - & & - & \\
\hline SMA41 & 981 & & & • & \\
\hline SMA40 & 956 & - & & - & \\
\hline SMA39 & 931 & & & - & \\
\hline SMA38 & 906 & - & & • & \\
\hline SMA37 & 881 & & & - & \\
\hline SMA36 & 856 & - & & & \\
\hline SMA34 & 806 & - & & • & \\
\hline SMA33 & 781 & & & - & \\
\hline SMA32 & 756 & - & & - & \\
\hline SMA31 & 731 & & & • & \\
\hline SMA30 & 706 & - & - & - & \\
\hline SMA29 & 681 & & - & - & \\
\hline SMA28 & 656 & - & - & • & \\
\hline SMA27 & 636 & & - & - & \\
\hline SMA26 & 621 & - & - & • & \\
\hline SMA11_mag & 616 & & & & - \\
\hline SMA25 & 606 & & - & - & \\
\hline SMA24 & 581 & - & - & - & \\
\hline SMA10_mag & 566 & & & & • \\
\hline SMA23 & 556 & & - & - & \\
\hline SMA22 & 531 & - & - & - & \\
\hline SMA09_mag & 516 & & & & - \\
\hline SMA21 & 506 & & - & - & \\
\hline SMA20 & 481 & - & - & - & \\
\hline SMA19 & 456 & - & - & - & - \\
\hline SMA18 & 431 & & - & - & \\
\hline SMA17 & 406 & - & - & - & - \\
\hline SMA16 & 381 & & - & - & \\
\hline SMA15 & 356 & - & - & - & \\
\hline SMA06_mag & 336 & & & & - \\
\hline SMA14 & 331 & & - & - & \\
\hline SMA13 & 306 & - & - & - & \\
\hline SMA05_mag & 286 & & & & - \\
\hline SMA12 & 281 & & - & - & \\
\hline SMA11 & 256 & - & - & - & \\
\hline SMA04_mag & 236 & & & & - \\
\hline SMA10 & 231 & & - & - & \\
\hline SMA09 & 206 & - & • & - & \\
\hline SMA03_mag & 186 & & & & - \\
\hline SMA08 & 181 & & - & - & \\
\hline SMA07 & 156 & - & - & - & \\
\hline SMA06 & 131 & & - & - & \\
\hline SMA05 & 106 & - & - & - & - \\
\hline SMA04 & 081 & & • & • & \\
\hline SM27_mag & 076 & & & & - \\
\hline SMA03 & 056 & - & - & - & \\
\hline SMA01_mag & 040 & & & • & - \\
\hline SMA01_mag & 036 & & & & - \\
\hline SMA02 & 031 & & - & - & \\
\hline SMM45_mag & 023 & & & & - \\
\hline SM28_mag & 021 & & & - & - \\
\hline $\mathrm{SM} 28 \_\mathrm{mag}$ & 016 & & & & - \\
\hline SMM 43_mag & 014 & & & & - \\
\hline SM29_mag & 011 & & & & - \\
\hline SM55e_mag & 008 & & & & - \\
\hline SMM 42_mag & 007 & & & & - \\
\hline SMA01 & 006 & - & - & - & \\
\hline SMM 41_mag & 003 & & & & - \\
\hline SMA-01 & -001 & • & • & • & • \\
\hline
\end{tabular}


Table 2 (Continued)

\begin{tabular}{|c|c|c|c|c|c|}
\hline Sample & Level (m) & Calcareous nannofossils & Pollen & $\delta^{18} \mathrm{O} \delta^{18} \mathrm{O} \delta^{18} \mathrm{O} \delta^{18} \mathrm{O} \delta^{18} \mathrm{O} \delta^{18} \mathrm{O} \delta^{18} \mathrm{O}$ & Magneto \\
\hline SMM40A_mag & -003 & & & & - \\
\hline SM22 mag & -004 & & & - & - \\
\hline SM51_mag & -005 & & & & - \\
\hline SM52 mag & -007 & & & & - \\
\hline SMA17__mag & -008 & & & - & - \\
\hline SMA17 mag & -010 & & & & - \\
\hline SM23_mag & -012 & & & - & - \\
\hline LU02_mag & -015 & & & & - \\
\hline SM21_mag & -016 & & & - & - \\
\hline SM40-3 & -020 & & & . & . \\
\hline SMA-02 & -025 & & - & - & \\
\hline LU04B mag & -026 & & & & • \\
\hline SM24_mag & -028 & & & - & - \\
\hline LU05A_mag & -029 & & & & - \\
\hline SM39 mag & -031 & & & - & - \\
\hline SM25_mag & -034 & & & - & - \\
\hline SM54b_mag & -037 & & & & - \\
\hline SM20 mag & -039 & & & - & . \\
\hline SM30B_mag & -041 & & & & - \\
\hline SM30_mag & -044 & & & - & - \\
\hline SMA-03 & -050 & . & . & . & \\
\hline SM31A_mag & -059 & & & & - \\
\hline SM31B mag & -061 & & & & - \\
\hline SMA- 04 & -075 & & - & . & \\
\hline LU21A_mag & -075 & & & & - \\
\hline SM32A mag & -079 & & & & - \\
\hline LU20A_mag & -081 & & & & - \\
\hline LU20B_mag & -083 & & & & - \\
\hline LU22B mag & -089 & & & & - \\
\hline LU22C mag & -091 & & & & . \\
\hline LU23A_mag & -093 & & & & - \\
\hline LU23B mag & -095 & & & & - \\
\hline LU23C_mag & -097 & & & & - \\
\hline SMA- $0 \overline{5}$ & -100 & - & - & - & \\
\hline LU24A mag & -101 & & & & . \\
\hline LU24B_mag & -103 & & & & - \\
\hline LU25A_mag & -105 & & & & - \\
\hline LU25B mag & -107 & & & & . \\
\hline LU25C_mag & -109 & & & & - \\
\hline SM33 mag & -110 & & & & - \\
\hline LU26Ā_mag & -111 & & & & - \\
\hline SM34B mag & -112 & & & & - \\
\hline LU26B mag & -113 & & & & . \\
\hline LU26C_mag & -115 & & & & - \\
\hline SMA- $0 \overline{6}$ & -125 & & - & - & \\
\hline SM35A mag & -139 & & & & - \\
\hline SM35B_mag & -141 & & & & - \\
\hline SMA- $0 \overline{7}$ & -150 & - & - & . & \\
\hline SMA-08 & -175 & & . & . & \\
\hline SMA-09 & -200 & • & - & • & \\
\hline SMA-10 & -225 & & . & • & \\
\hline SMA-11 & -250 & . & . & . & \\
\hline SMA-12 & -275 & & - & • & \\
\hline SMA-13 & -300 & . & . & • & \\
\hline SMA-14 & -325 & & - & - & \\
\hline SMB01 & -350 & • & - & • & \\
\hline SMB02 & -375 & & - & - & \\
\hline SMB03 & -400 & • & & • & \\
\hline SMB04 & -425 & & & • & \\
\hline SMB05 & -450 & - & & - & \\
\hline SMB06 & -475 & & & • & \\
\hline SMB07 & -500 & . & & . & \\
\hline SMB09 & -550 & - & & - & \\
\hline SMB10 & -575 & & & • & \\
\hline SMB11 & -600 & . & & • & \\
\hline SMB12 & -625 & & & - & \\
\hline SMB13 & -650 & • & & • & \\
\hline SMB15 & -700 & . & & . & \\
\hline SMB17 & -750 & • & & • & \\
\hline SMB19 & -800 & - & & . & \\
\hline SMB20 & -825 & & & . & \\
\hline SMB21 & -850 & • & & • & \\
\hline
\end{tabular}


Table 2 (Continued)

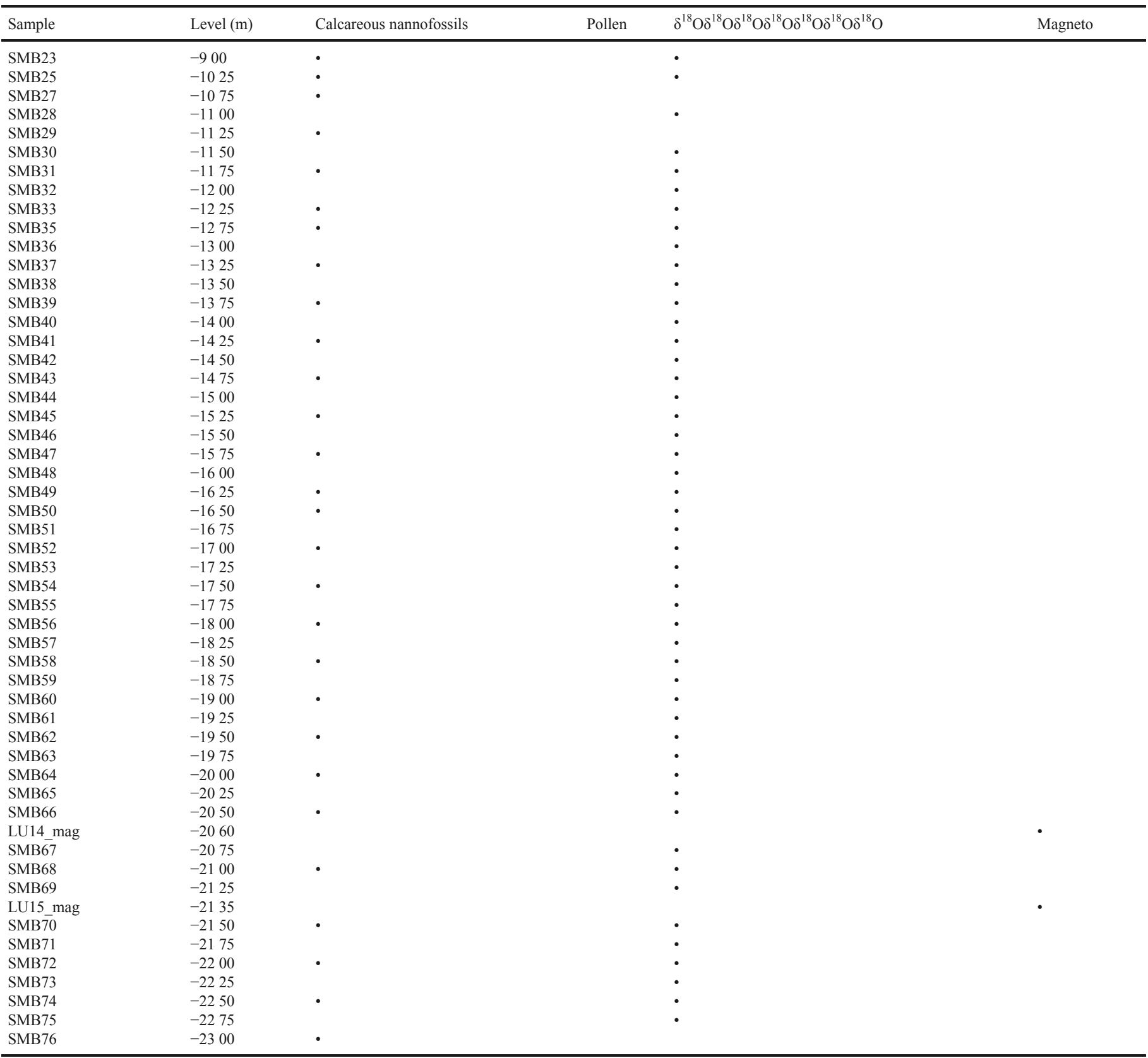

The "lightest" $\delta^{18} \mathrm{O}$ values of $U$. peregrina point to the Maximum Eustatic (=global) Depth (MED) of MIS 21 and MIS 19. The MED intervals precede the Local Maximum Depth (LMD) horizons, which are marked by sediment starvation with development of firmgrounds rich in Neopycnodonte cochlear (Facies B; Fig. 3, Table 1).

\subsection{Calcareous nannofossils}

Indigenous calcareous nannofossils are present with variable abundances throughout the studied interval, with highest concentrations and best preservation in the fine-grained intervals corresponding to full MIS 21 and MIS 19.

Unfortunately, the chronostratigraphic interval between late MIS 25 and late MIS 16 (from ca. +0.9 to ca. $+0.6 \mathrm{Ma}$ ), which includes the VdM record, is especially difficult to assess by means of a conventional marine biostratigraphy. Calcareous nannofossil assem- blages show no significant evolutionary changes in the Central Mediterranean basin between the Base common $(\mathrm{Bc})$ of calcareous nannofossil Gephyrocapsa sp.3/omega (sensu Rio, 1982), calibrated with MIS 25 (base of the "Pseudoemiliania lacunosa" Zone, ca. 950 $\mathrm{ka}$; Castradori, 1993) and the Top (T) of the species (MIS 15; Raffi et al., 2006). However, this interval is marked both by episodes of temporary appearance/disappearance and fluctuations in the relative abundance of different species within the genus Gephyrocapsa, which occur at the regional scale and probably reflect physical and chemical changes in the photic zone (e.g., Raffi et al., 2006).

At VdM, the distribution pattern of the total gephyrocapsids assemblage shows a striking resemblance with the $\delta^{18} \mathrm{O}$ record of $U$. peregrina, with peaks of abundance centered on the LMD intervals of MIS 21 and MIS 19 (Fig. 6a).

Being considered indicative of warm, nutrient-rich surface waters and low salinity (Maiorano and Marino, 2004), Gephyrocapsa 


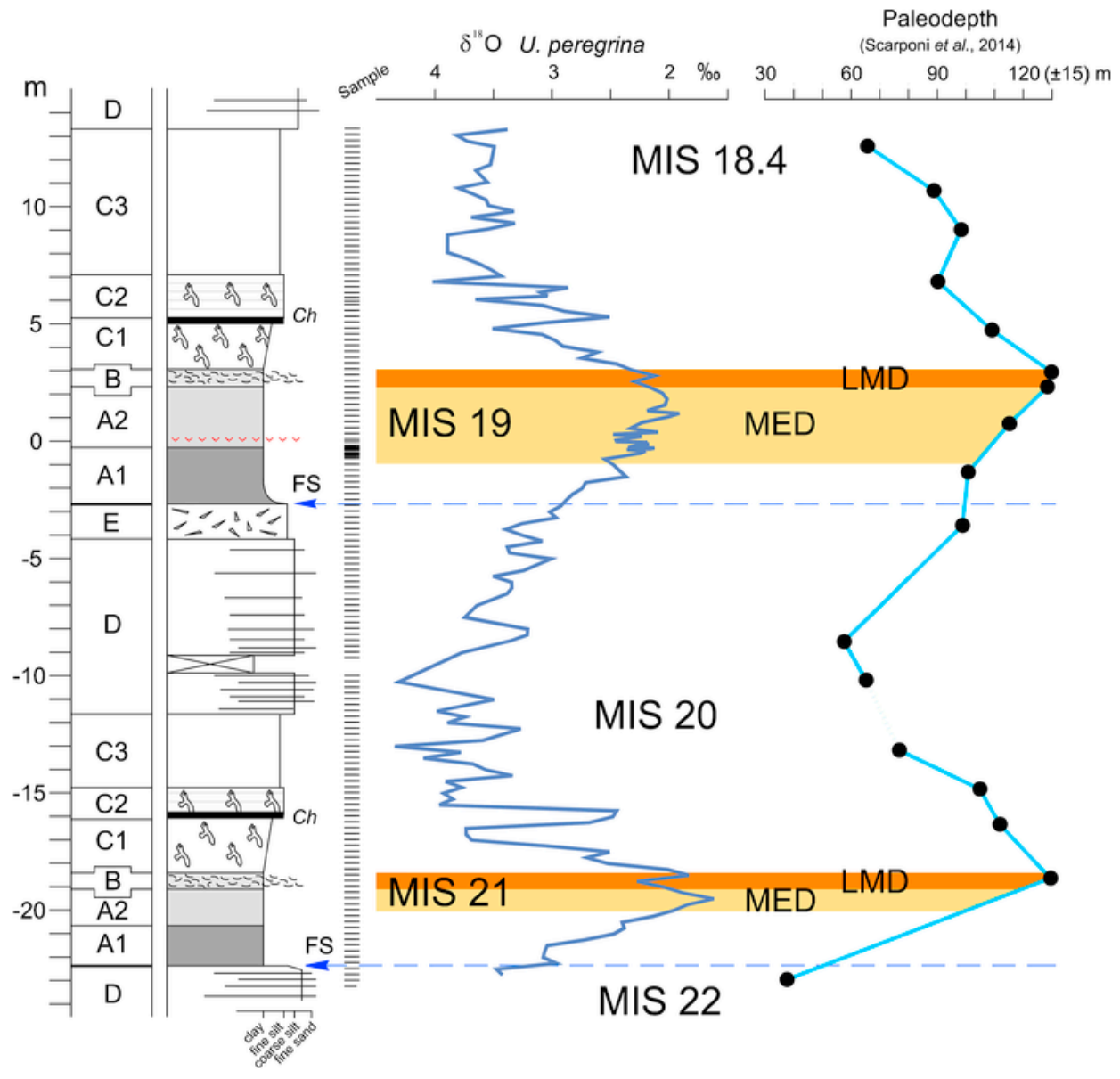

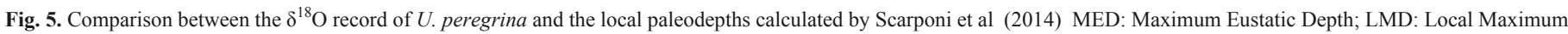

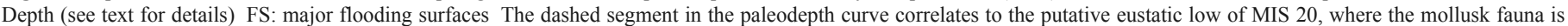
sparse and statistically insignificant

sp.3/omega is common to very abundant during interglacial intervals and rare to absent during glacial periods. However, long records from the central Mediterranean (e.g., Castradori, 1993; Maiorano and Marino, 2004) concur that G. sp.3/omega is extremely scarce during the MIS 19 interglacial, being conversely abundant in the contiguous MIS 21 and 17. This distribution, well documented in other sections of the Crotone Basin (Capraro et al., 2011), is for the first time recognized unambiguously in the VdM section (Fig. 6c).

Gephyrocapsa oceanica is believed to thrive in ecological conditions similar to those suggested for G. sp.3/omega (e.g., Thierstein et al., 1977; Flores et al., 1999; Sprovieri et al., 2003; Melinte, 2005). In the VdM section, the MIS 19 interglacial is dominated by this species (predominantly represented by specimens $\geq 4 \mu \mathrm{m}$ in size; Fig. $6 \mathrm{~b}$ ), as also reported by Sprovieri et al. (1998) for the Sicilian Strait.

The species $G$. caribbeanica is considered indicative of cool to cold surface waters (e.g., Wells and Okada, 1996, 1997; Flores et al., 1999; Villa et al., 2005), which are reasonably correlated to glacial intervals. Being the species confined to glacial events and their terminations (Fig. 6d), its distribution pattern in the VdM section seems to confirm its preference for cool/cold waters. An excellent documentation is provided by the expanded termination of MIS 20, where the deep-dwelling Globorotalia inflata, indicative of a persistently cold, vertically mixed water column (Pujol and Vergnaud Grazzini, 1995; Hemleben et al., 1989) is abundant (Capraro et al., 2005; our unpublished data).
Regrettably, it was not possible to detect the T of Reticulofenestra asanoi, which would occur within the upper MIS 22 sands (Raffi et al., 2006), where nannofossils are only represented by a reworked assemblage (Rio et al., 1996).

We also accomplished a qualitative evaluation of the amount of reworked nannofossils with respect to the total indigenous assemblage (Fig. 6e). Estimates have been calculated as follows: A (abundant $)=1-2$ reworked specimens per field; $\mathrm{C}($ common $)=1$ reworked specimen per $1-2$ fields; $F$ (few) $=1$ specimen per 5 fields; $R$ (rare) $=1$ specimen per more than 10 fields. As expected, the maximum input of displaced material occurs in correspondence to glacial intervals (MIS 22, MIS 20, MIS 18.4), characterized by low sea level and massive sediment yield to the basin. In contrast, a native nannofossil population is dominant during interglacial periods, when the terrestrial sources of terrigenous input were farthest from the sedimentation area.

\subsection{Pollen}

We processed and analyzed 46 samples, which increased greatly the information on the stratigraphic interval straddling MIS 19 with respect to that previously available (17 samples; Capraro et al., 2005). The alternation between different vegetation states permit subdividing the studied interval into three main segments (ecozones), as follows (Fig. 7). 


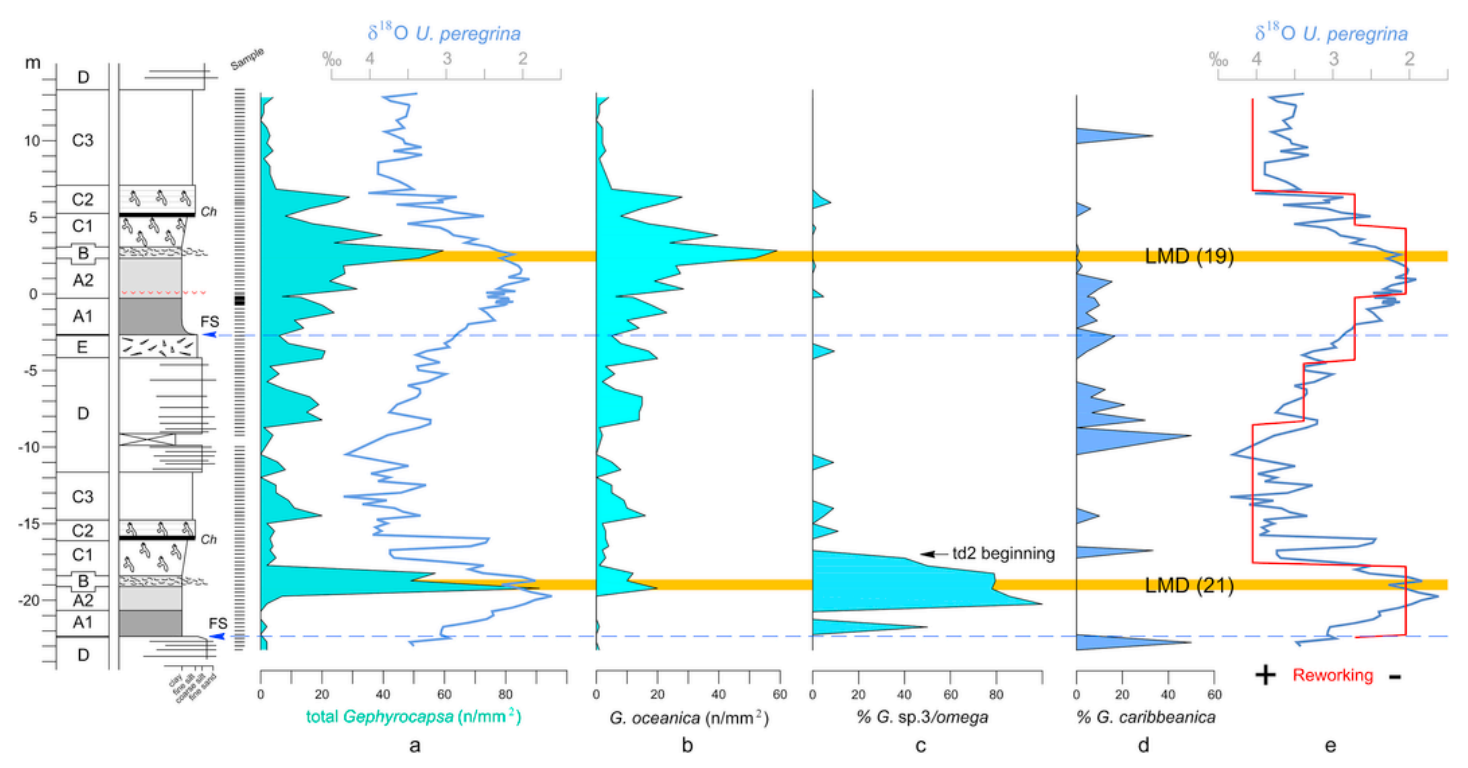

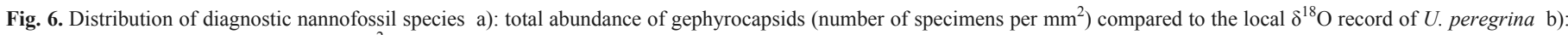

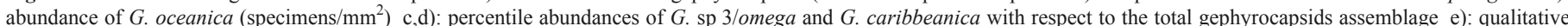

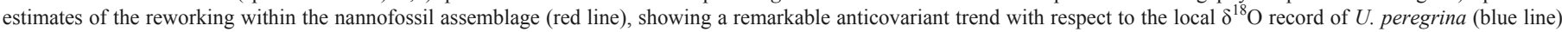

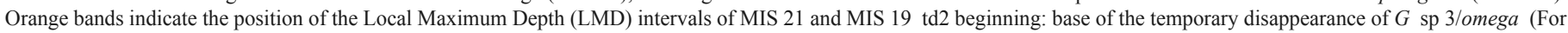
interpretation of the references to colour in this figure legend, the reader is referred to the web version of this article )

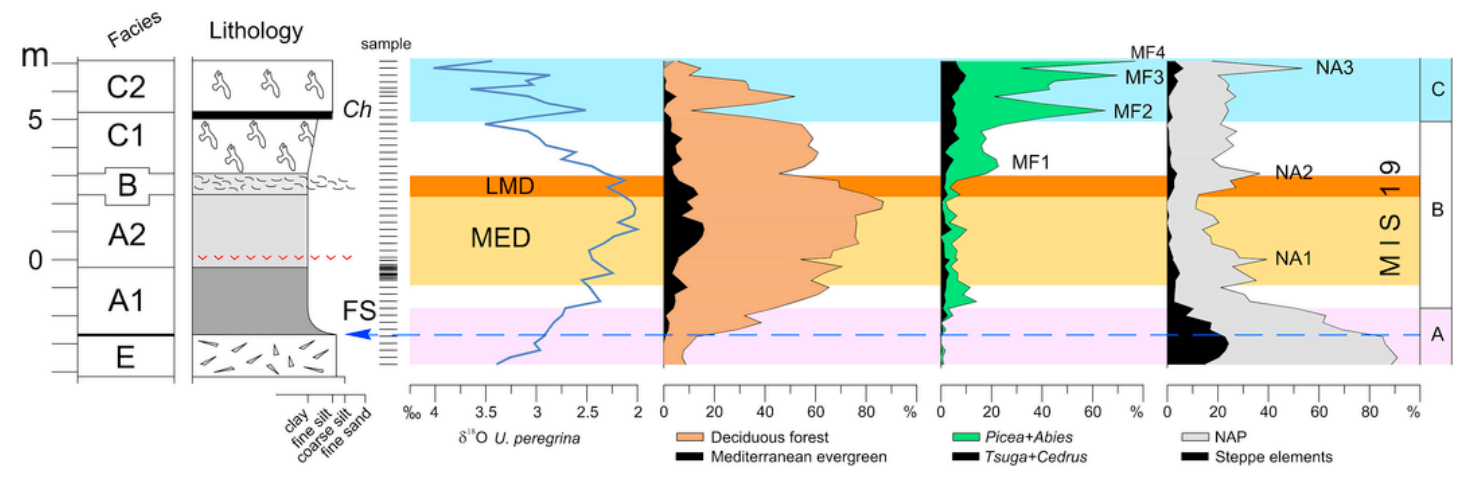

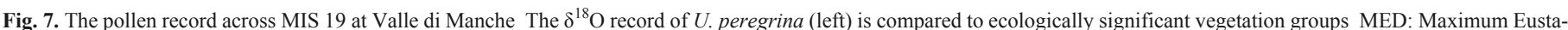

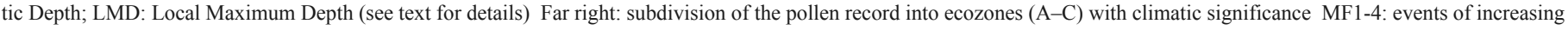
boreal ("cold") conifer forest, suggesting cool/cold and humid climates NA1-3: events with abundance of non-arboreal plants, indicative of arid conditions

Segment A: non-arboreal plants (both steppe plants and common herbs) are dominant. By comparison to the present-day distribution of vegetation in the Central Mediterranean area, this vegetation points to very dry climates (Capraro et al., 2005; references therein; Bertini et al., 2015). However, the abundance of non-arboreal plants in Segment A, which correlates to the glacial termination of MIS 20, may also be a consequence of the landward retreat of fluvial entry-points in response to the sea-level rise associated to the deglaciation, with decreasing riverine transport of pollen from the inner mainland in favor of airborne grains from the littoral areas.

Segment B: it corresponds to the full MIS 19 interglacial (interval B in Fig. 7). Temperate (mesothermic) forest elements, such as Tilia, Carpinus and Ostrya, with deciduous Quercus the dominant pollen type, attain to very high percentages. Evergreen trees, such as Quercus ilex, Olea and Phillyrea are also well represented. This forest assemblage is grossly similar to the vegetation that nowadays prospers in the inner mainland of the Mediterranean regions (Noirfalise et al., 1987), suggesting that MIS 19 was characterized by a "modern" vegetation and climates similar to the present day. However, we ob- served a significant number of pollen grains of "Tertiary" elements, such as Carya and Pterocarya, presently not indigenous in the Mediterranean basin (e.g., Bertini, 2003). This vegetation state is interrupted by three minor events (NA1-2, MF1) that possibly indicate transient climatic changes.

Segment $\mathrm{C}$ is characterized by a marked instability, as the "mountain" forest group (mainly Abies) increases gradually beginning from the peak $\delta^{18} \mathrm{O}$ interglacial and becomes intermittently dominant at the transition to glacial MIS 18.4, with a cluster of discrete peaks of growing amplitude (events CF2-4 in Fig. 7). "Exotic" conifers for the modern Mediterranean flora (Picea, Tsuga and Cedrus) are also common. This assemblage points to cool/cold climates, with a minimum annual rainfall rate significantly higher than the present day in the area.

Analysis of the pollen data also reveals a number of minor fluctuations, which are repeatedly in keeping with changes in the local stratigraphy and/or oscillations in the isotopic curve.

The temperate forest reaches its highest abundance at ca. $2 \mathrm{~m}$ level, immediately below the base of the LMD interval (Fig. 7), 
which also documents the period of maximum sediment starvation. From this point upwards, the temperate forest declines, and a remarkable increase of the NAP group is observed that peaks in correspondence to the top of the LMD interval (event NA1 in Fig. 7). Immediately above, sediment accumulation rates and arboreal pollen increase again, with a short peak of "mountain" forest elements (MF1 event; Fig. 7). The glacial inception of MIS 18 (Segment C) is characterized by a marked instability in both $\delta^{18} \mathrm{O}$ and vegetation, which alternates rapidly between two forested states. Specifically, the short-lived intervals of "light" $\delta^{18} \mathrm{O}$ (MF2-4 events in Fig. 7) are characterized by sudden increases in "mountain" forest elements, while a temperate deciduous forest develops, albeit with decreasing values, during the intervening "heavy" $\delta{ }^{18} \mathrm{O}$ event.

As discussed above, being consistent with the stratigraphic architecture, this progression can equally be explained as a signal of gradually deteriorating climates and/or the response to changes in the sedimentary yield to the basin. Indeed, these oscillations may reflect either the altitudinal migration of vegetation belts in response to changing climates, or the amount and type of pollen grains transported to the basin via river runoff. Higher rainfall rates would increase the drainage within the catchment basin, thus augmenting the river runoff and the transport of "mountain" pollen grains to the coast, and vice-versa, independently from the dynamics of vegetation belts. Anyhow, we stress that the concurrently erratic behavior of pollen and $\delta^{18} \mathrm{O}$ at the MIS 19 - MIS 18 transition is hardly incidental, as confirmed by the occurrence of similar sedimentary and isotopic patterns at the beginning of MIS 20 (Fig. 3).

\subsection{Magnetostratigraphy}

The magnetostratigraphic record achieved at VdM improves that presented in Rio et al. (1996), where the M-B geomagnetic reversal was reported to occur within a ca 1.5 m-thick interval.

Characteristic remanent magnetization (ChRM) directions for the sediments were isolated by means of an AF demagnetization in 15 steps up to $70 \mathrm{mT}$ and, for 18 specimens, by a stepwise thermal demagnetization in 9 steps up to $420^{\circ} \mathrm{C}$. We obtained ChRM directions from 38 samples, with magnetization components isolated by the principal component analysis of Kirschvink (1980). For the fine-grained sediments of the entire VdM succession, a stable ChRM was identified after the removal of a viscous component at $\mathrm{AF}<10-20 \mathrm{mT}$ (see also Rio et al., 1996). In the upper part of the section, demagnetization analyses indicate a stable paleomagnetic behavior, as the demagnetization vectors are aligned along linear paths towards the origin after removal of little viscous low coercivity remanence component; therefore, ChRM directions were computed by fitting a linear component between $10 \mathrm{mT}$ and $60-70 \mathrm{mT}$. A normal polarity is documented in the interval from $+0.14 \mathrm{~m}$ to $+6.16 \mathrm{~m}$, while a stable reverse polarity is reported from $-0.11 \mathrm{~m}$ to the bottom of the studied interval $(-21.35 \mathrm{~m})$ (see ChRM inclination values in Fig. 8a).

Limited to the lower part of the studied interval, below ca $-0.6 \mathrm{~m}$, ChRM analyses indicate the acquisition of a spurious gyromagnetic remanent magnetization during the $\mathrm{AF}$ demagnetization treatment in fields higher than $50 \mathrm{mT}$. This behavior points to the presence of variable amounts of iron sulphides, probably greigite $\left(\mathrm{Fe}_{3} \mathrm{~S}_{4}\right.$; $\mathrm{Fu}$ et al., 2008), which gradually increase downwards to the bottom of the studied interval. For these samples, ChRM directions were computed by fitting a straight line to directions measured between ca $10 \mathrm{mT}$ and $50 \mathrm{mT}$.

We performed a number of rock magnetic analyses in order to investigate the magnetic mineralogy carrying the characteristic remanence. The matter is discussed thoroughly in a dedicated paper (Macrì et al., submitted), to which we refer for further details. Rock magnetic investigations indicate that magnetite is the main magnetic carrier for all of the measured specimens along the section, confirming the presence of iron sulphides only in the lower part of the stratigraphy, well below the "Pitagora ash" (Macrì et al., submitted).

Conventional paleomagnetic techniques and data treatment that have been used in this study point to an unequivocal recognition of the M-B geomagnetic transition in a $3 \mathrm{~cm}$-thick interval between
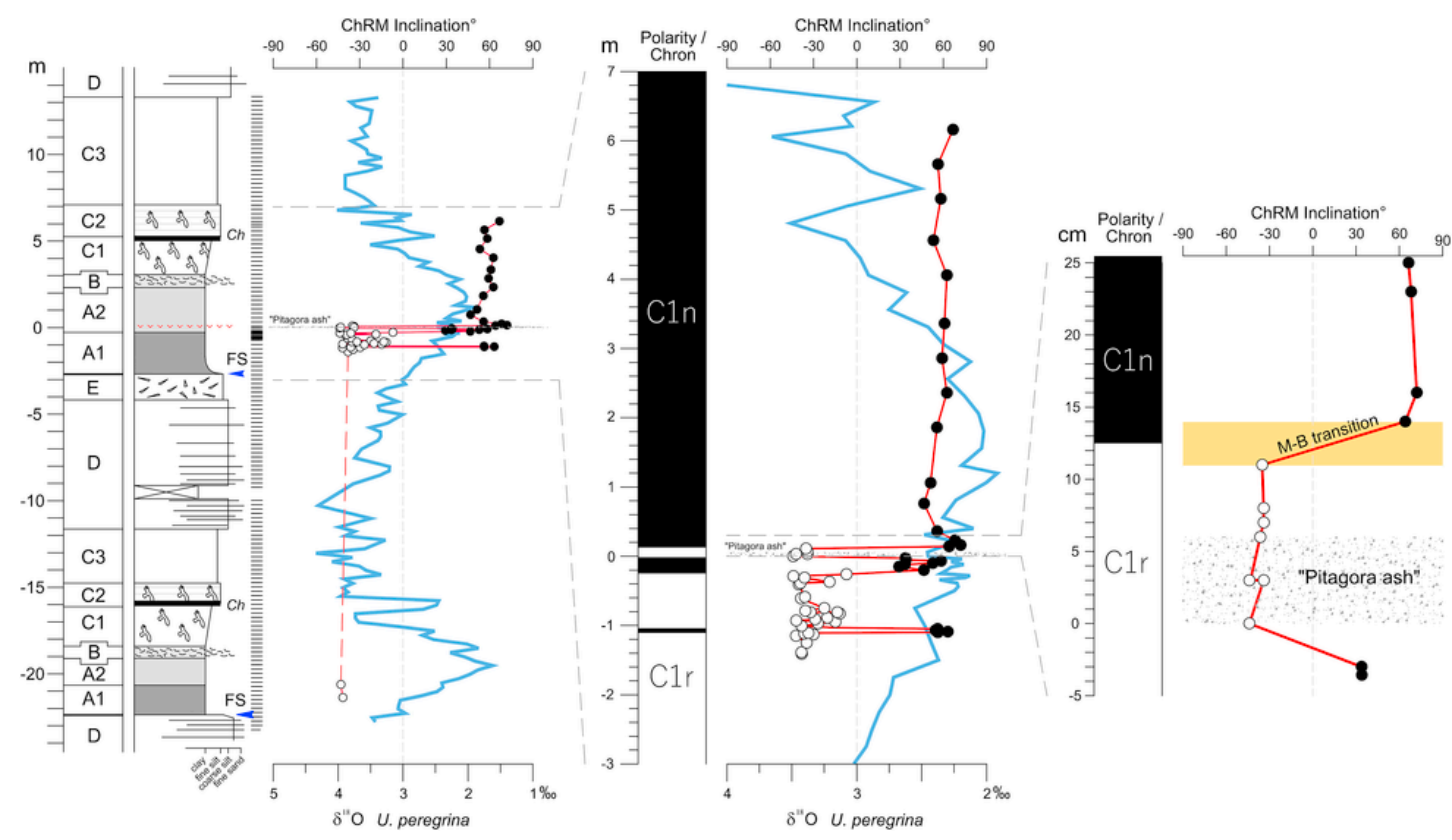

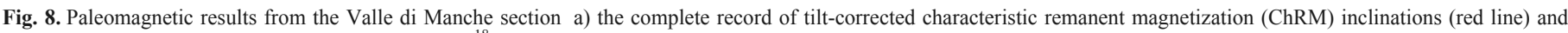

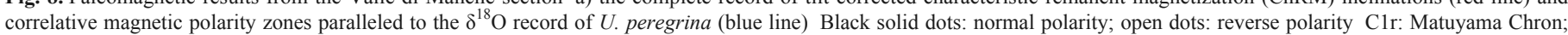

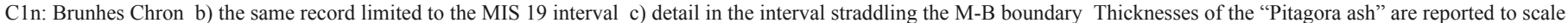
The solid orange band indicates the M-B transition (For interpretation of the references to colour in this figure legend, the reader is referred to the web version of this article ) 
+0.11 and $+0.14 \mathrm{~m}$ (midpoint of the transition at $+0.125 \mathrm{~m}$; Fig. $8 \mathrm{~b}$ ) above the "Pitagora ash". Two anomalous short intervals of normal polarity were detected from $-0.03 \mathrm{~m}$ to $-0.2 \mathrm{~m}$ and from -1.05 to $-1.10 \mathrm{~m}$ (Fig. 8a), which might possibly be related to remagnetization processes (Macrì et al., submitted).

\section{Age model}

An essential prerequisite in reconstructing a robust age model is the choice of an appropriate tuning target. As a common practice, individual isotope records worldwide are calibrated via the comparison to astronomically tuned, benthic $\delta^{18} \mathrm{O}$ deep-water successions (e.g. Shackleton et al., 1990), or $\delta^{18} \mathrm{O}$ stacks such as that of Lisiecki and Raymo (2005). However, geographic and oceanographic differences between the study area and the open ocean may be vast and potentially misleading. Therefore, the most suitable tuning target should be chosen taking into account both the local depositional setting and circulation systems, as well as the regional evapotranspiration and temperature budgets.

\subsection{Present-day oceanographic setting}

The Crotone Basin is located at the northwestern margin of the Ionian Sea (Central Mediterranean; Fig. 9). The interplay between regional freshwater and heat budgets promotes an anti-estuarine thermohaline circulation at the basin scale, sustained by a surface in-flow through the straits of Gibraltar and a congruent deep-water out-flow (Béthoux et al., 1992). The Atlantic inflow evolves rapidly to form the Modified Atlantic Waters (MAW), which are constrained to a ca. 200 $\mathrm{m}$-thick surface layer that experiences a gradual in-crease in temperature and salinity while flowing eastward (Wüst, 1961; Malanotte-Rizzoli and Hecht, 1988). During the winter sea-son, cold northern winds cause heat loss and vertical convection. This eventually results in sinking of the MAW and enucleation of the Levantine Intermediate Waters (LIW; Malanotte-Rizzoli and Hecht, 1988; Lascaratos et al., 1993), which flow westward at a depth between 200 and $600 \mathrm{~m}$, persistently below the MAW (Borzelli et al., 2009; Gačić et al., 2011;

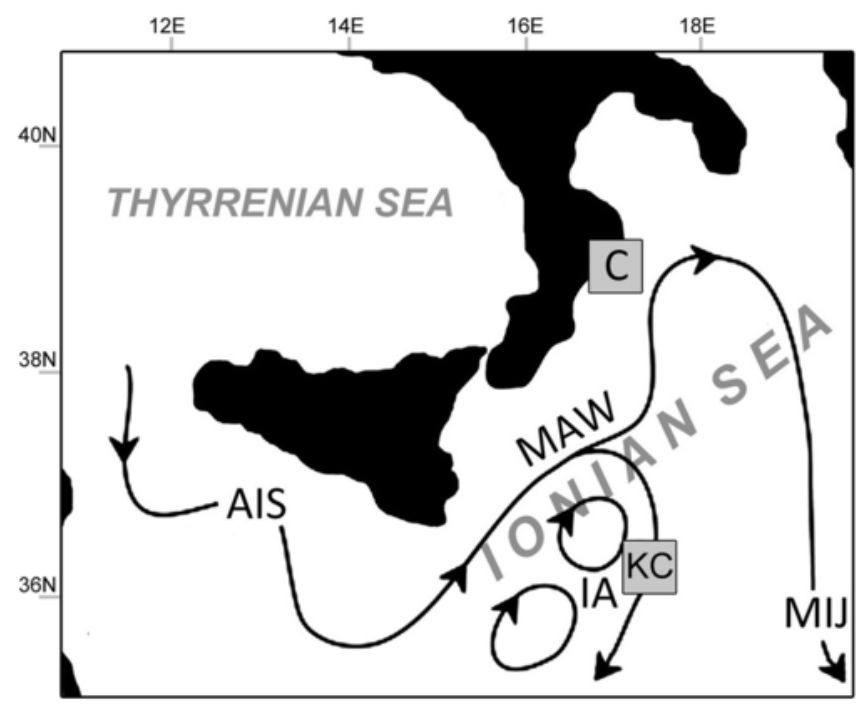

Fig. 9. - The upper thermohaline circulation and water mass pathways in the central Mediterranean (modified from Malanotte-Rizzoli et al , 2014) Solid lines mark water mass pathways and permanent dynamic features AIS: Atlantic-Ionian Stream MAW: Modified Atlantic Waters IA: Ionian Anticyclones MIJ: Mid-Ionian Jet C: location of the Crotone Basin KC: location of Core KC01b (Castradori, 1993)
Bensi et al., 2013). The LIW also play a key role in generating the Mediterranean Deep Waters (MDW), which circulate at the bottom of the basin (e.g., Malanotte-Rizzoli et al., 1999, 2014).

The isotopic composition of surface waters in the Ionian Sea is consistent, with minor variations at the basin scale (Pierre, 1999). Surface waters offshore from the Crotone peninsula do not differ significantly, in terms of temperature and salinity, from those of the open Ionian Sea (Fig. 9; Malanotte-Rizzoli et al., 1997). By contrast, composition of the MAW (Pierre, 1999) is very different from both the Atlantic (Frew et al., 2000) and the deeper Mediterranean waters (i.e, LIW and MDW). Accordingly, the correlation between regional shelf/ slope $\delta^{18} \mathrm{O}$ successions and the deep-sea records, both from the open ocean and the Mediterranean, should be approached very carefully.

\subsection{The target curve}

Mediterranean $\delta^{18} \mathrm{O}$ records straddling the MIS 21-MIS 19 interval are not common. Furthermore, only few have been calibrated by means of an independent chronology. One of the longest and best-documented $\delta^{18} \mathrm{O}$ successions available for the Central Mediterranean area is the planktonic record of Globigerinoides ruber reconstructed for the sapropel-bearing $\mathrm{KC} 01 \mathrm{~b}$ core, recovered in the central Ionian Sea (Castradori, 1993, Fig. 9). Lourens (2004) exploited the sapropel record of the $\mathrm{KC} 01 \mathrm{~b}$ core for achieving an astronomical tuning of the succession, which was also validated by comparison to other Mediterranean and open ocean successions. The $\mathrm{KC} 01 \mathrm{~b}$ record represents the backbone of the Mediterranean isotopic Stack of Wang et al. (2010) (W2010 herafter), a merger of individual planktonic $\delta^{18} \mathrm{O}$ records recovered in the Central and Eastern Mediterranean area. The shape of the W2010 approximates closely that of the KC01b core alone, confirming that the isotopic composition of surface waters in the open Central-Eastern Mediterranean is similar at the regional scale (Pierre, 1999). The sapropel chronology of Lourens (2004) was recently revised by Konijnendijk et al. (2014) based on the assumption that the $\mathrm{Al} / \mathrm{Ti}$ ratio in sediments is the best proxy of the precessional forcing on the African monsoon system, which controls the Nile riverine input and the eventual deposition of sapropel layers in the eastern Mediterranean basins.

Konijnendijk et al. (2015) employed the same approach for tuning the Mediterranean benthic $\delta^{18} \mathrm{O}$ stack (K2015 hereafter), which was reconstructed by combining the $\delta^{18} \mathrm{O}$ records of two deep-sea ODP cores recovered in the open Eastern Mediterranean (water depth of ca. $2000 \mathrm{~m}$ and $2600 \mathrm{~m}$ b.s.1.). The Authors strive to demonstrate that the mode and tempo of the events documented in the K2015 record match those of the LR04 stack of Lisiecki and Raymo (2005), thus implying that the Eastern Mediterranean Deep Waters (EMDW) mimic the deep open ocean signal. At once, this conclusion undermines the suitability of the K2015 stack as target for calibrating the shelfal VdM $\delta^{18} \mathrm{O}$ record, which essentially reflects the dynamics of the much shallower MAW.

Comparison between the K2015 and W2010 records shows that the age models of Lourens (2004) and Konijnendijk et al. (2015) differ by a significant and variable offset that, in the interval of interest, attains to a maximum of $\sim 8 \mathrm{kyr}$ at glacial terminations and $\sim 6 \mathrm{kyr}$ at glacial inceptions (Fig. 10a). The different archives (i.e., benthic vs. planktonic species) and tuning methods employed for reconstructing each record may account for this mismatch, which however justifies only partly the observed offset. Konijnendijk et al. (2014) admit that in the critical interval correlative to the VdM record (between $700 \mathrm{ka}$ and $950 \mathrm{ka}$ ), where no sapropel layers are present, 

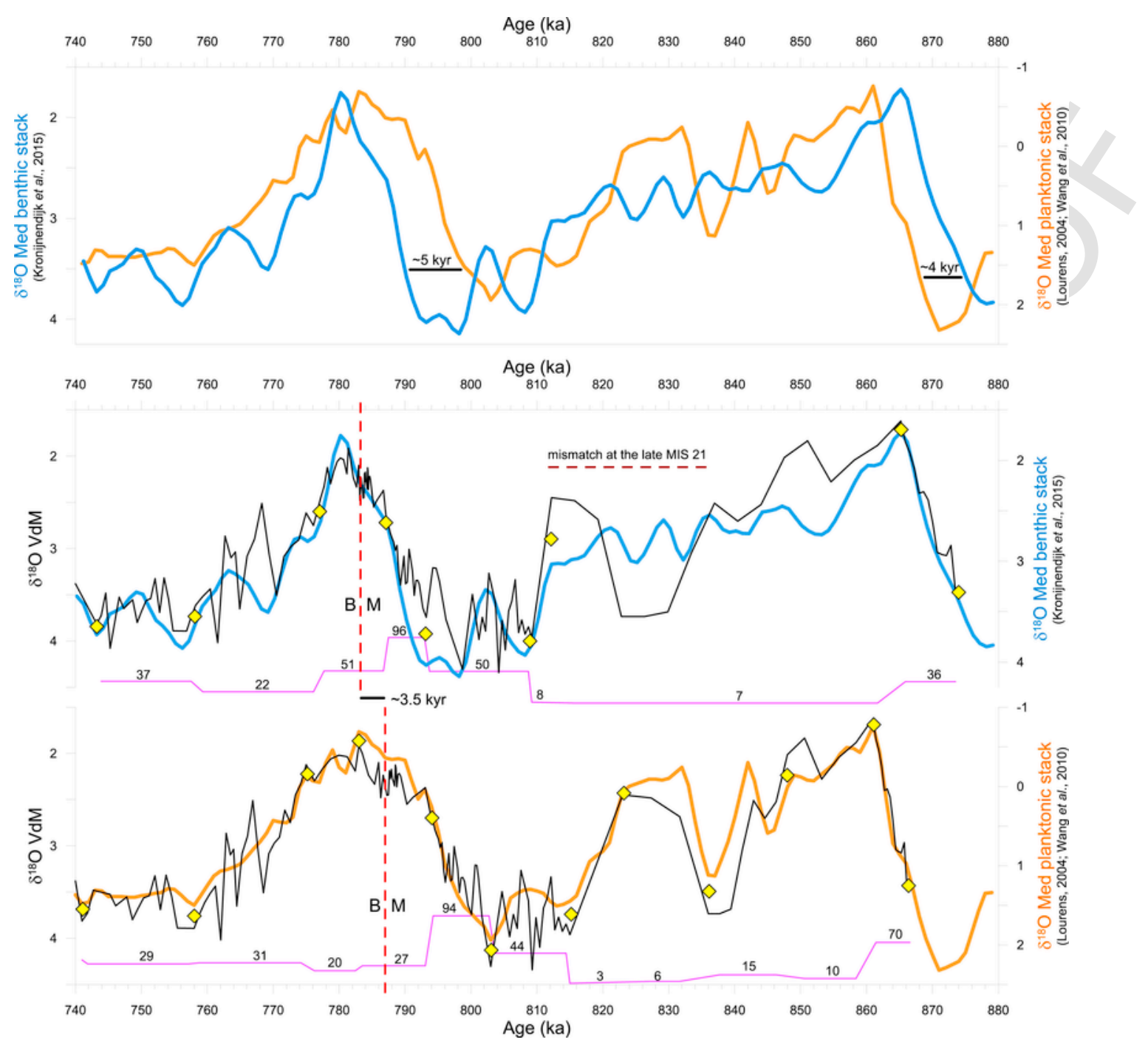

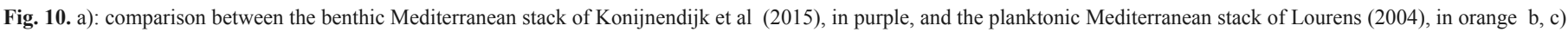

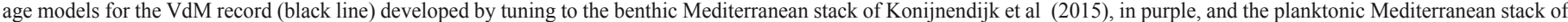

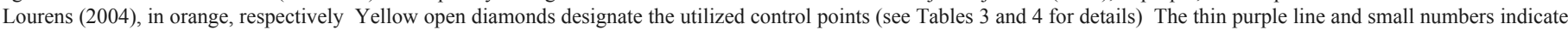

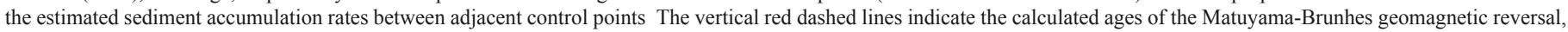
which differ by ca $35 \mathrm{kyr}$ The horizontal dashed line (late MIS 21) indicates the interval of critical mismatch between the VdM and K2015 records

the response of proxies is contradictory and the tuning is problematic, suggesting that the ensuing chronology may be ambiguous.

We attempted a visual correlation between the VdM and K2015 records, showing that the correspondence is questionable (Fig. 10b). This is not unexpected because, as anticipated, the K2015 and VdM records reflect the dynamics of vastly different water masses, namely the MAW and EMDW. Correlation is based on 9 control points (Table 3) that provide a reasonable match only at the full MIS 19 interglacial and, less convincingly, in the contiguous intervals (Fig. 10b). Correspondence is extremely poor in the interval corresponding to the late MIS 21 (ca. between 855 and $815 \mathrm{ka}$ ), where the K2015 stack exhibits a unique cluster of four "light" $\delta{ }^{18} \mathrm{O}$ events that prevents any reasonable attempt of correlation to the VdM record (Fig. 10b).

On the contrary, comparison between the VdM and $\mathrm{W} 2010 \delta^{18} \mathrm{O}$ curves, based on 12 control points (Table 4), shows a striking likeliness (Fig. 10c), confirming that the VdM and W2010 records reflect similar seawater properties (Fig. 9). Indeed, the estimated water depth at VdM during the deposition of the SM2 unit oscillates between ca.
60-150 m (Scarponi et al., 2014), well into the range at which the MAW reside. In spite of the similar patterns shown by the VdM and W2010 records, absolute $\delta^{18} \mathrm{O}$ values are expectedly dissimilar, in response to local influences such as riverine input, evapotranspiration and small-scale temperature gradients. In the case of infaunal species sensitive to pore-water conditions during the shell calcification, such as Uvigerina peregrina, differences in depth habitats and microhabitat effects are especially significant as well. However, given the short distance between the $\mathrm{KC} 01 \mathrm{~b}$ recovery site and the Crotone Basin (ca. $300 \mathrm{~km}$; Fig. 9), we can assume that the $\delta^{18} \mathrm{O}$ events documented by the VdM and W2010 records are virtually synchronous.

The chronology of Konijnendijk et al. (2015) is likely to represent an improvement with respect to that of Lourens (2004), and comparing the VdM succession to a benthic record may appear an advisable choice. However, given the problems discussed above and the poor visual correspondence, the ambiguous relationship between the $\mathrm{VdM}$ and K2015 records adds a large uncertainty to the reconstructed age model, which virtually defeats the purpose of exploiting a more refined chronology. Therefore, we decided to develop an age model 
Table 3

Stratigraphic and chronostratigraphic position of the control points employed for reconstructing the age model for Valle di Manche section and their corresponding age according to the K2015 stack of Konijnendijk et al (2015) The average sediment accumulation rates calculated between contiguous tie points are also reported

\begin{tabular}{llll}
\hline $\begin{array}{l}\text { Level } \\
(\mathrm{m})\end{array}$ & $\begin{array}{l}\text { Age } \\
(\mathrm{ka})\end{array}$ & Description & $\begin{array}{l}\text { Average sediment accumulation } \\
\text { rates }(\mathrm{cm} / \mathrm{kyr})\end{array}$ \\
\hline 1306 & 743 & MIS 18 & 37 \\
756 & 758 & MIS 18 & 22 \\
331 & 777 & Glacial inception of MIS 18 & 51 \\
-175 & 787 & $\begin{array}{l}\text { Midpoint of MIS 20-MIS 19 } \\
\text { transition }\end{array}$ & 96 \\
-750 & 793 & MIS 20 & 50 \\
-1550 & 809 & MIS 20 & 8 \\
-1575 & 812 & Glacial inception of MIS 20 & 7 \\
-1950 & 865 & MIS 21 5 & 36 \\
-2275 & 874 & $\begin{array}{l}\text { Midpoint of MIS 22-MIS 21 } \\
\text { transition }\end{array}$ & \\
\hline
\end{tabular}

\section{Table 4}

Stratigraphic and chronostratigraphic position of the control points employed for reconstructing the age model for Valle di Manche section and their corresponding age according to the W2010 stack of Wang et al (2010) The average sediment accumulation rates calculated between contiguous tie points are also reported

\begin{tabular}{llll}
\hline $\begin{array}{l}\text { Level } \\
(\mathrm{m})\end{array}$ & $\begin{array}{l}\text { Age } \\
(\mathrm{ka})\end{array}$ & Description & $\begin{array}{l}\text { Average sediment accumulation } \\
\text { rates }(\mathrm{cm} / \mathrm{kyr})\end{array}$ \\
\hline 1331 & 740 & MIS 18 & 29 \\
806 & 758 & MIS 18 & 31 \\
281 & 775 & Glacial inception of MIS 18 & 20 \\
120 & 783 & Peak MIS 19 & 27 \\
-175 & 794 & $\begin{array}{l}\text { Midpoint of MIS 20-MIS 19 } \\
\text { transition }\end{array}$ & 94 \\
-1025 & 803 & MIS 20 & 44 \\
-1550 & 815 & MIS 20 & 3 \\
-1575 & 823 & MIS 21 1 & 6 \\
-1650 & 836 & MIS 21 2 & 70 \\
-1825 & 848 & MIS 21 3 & 15 \\
-1950 & 861 & MIS 21 5 & Midpoint of MIS 22-MIS 21 \\
\hline
\end{tabular}

for the VdM succession employing the W2010 record as target curve. We estimate that the offset between our age model and the chronology provided by comparison to the K2015 curve is in the order of a few kyr, possibly smaller than the error commonly associated to the astronomical tuning method (ca. 5 kyr; Imbrie et al., 1984; Martinson et al., 1987).

According to our reconstruction, the studied record spans from ca. 740 to $870 \mathrm{ka}$ (Fig. 10). The proposed age model is consistent with the expected chronology and respectful of the raw data. Indeed, the $\mathrm{VdM} \delta^{18} \mathrm{O}$ record is virtually not stretched or deformed in the critical
MIS 20-MIS 18 interval with respect to the original stratigraphy (Fig. 3 ), suggesting that our age model is robust across MIS 19.

\subsection{Sediment accumulation rates}

The estimated sediment accumulation rates provide a simple yet valuable gauge of the robustness of an age model. Being calculated by linear interpolation, they change accordingly to the stratigraphic position of control points and their putative age. However, sediment accumulation rates must be coherent with the local depositional setting, and they should vary significantly only in correspondence to a congruent change in the physical stratigraphy.

The sediment accumulation rates calculated for the VdM section (Table 4) range from a minimum of ca. $3 \mathrm{~cm} / \mathrm{kyr}$ to a maximum of ca. $94 \mathrm{~cm} / \mathrm{kyr}$. As expected, relative minima characterize the fine-grained intervals corresponding to the interglacials of MIS 21 and MIS 19 (ca. 10 and $27 \mathrm{~cm} / \mathrm{kyr}$, respectively). In contrast, sedimentation rates increased during the MIS 20 glacial (up to ca. $44 \mathrm{~cm} / \mathrm{kyr}$ ) and during the MIS 22-MIS 21 and MIS 20-MIS 19 transitions (58 and $94 \mathrm{~cm} / \mathrm{kyr}$, respectively).

In the critical interval correlative to full MIS 19, i.e. across the M-B boundary, the average sediment accumulation rates are in the order of ca. $27 \mathrm{~cm} / \mathrm{kyr}$. These values are significantly higher than those (ca. $13 \mathrm{~cm} / \mathrm{kyr}$ ) proposed by Capraro et al. (2005), but more in keeping with those reported for the muddy intervals in many shelfal Pleistocene sections of the Crotone Basin (Capraro et al., 2011).

In general, sediment accumulation rates at $\mathrm{VdM}$ change in agreement with both the physical stratigraphy and the local $\delta^{18} \mathrm{O}$ curve, pointing to a strong glacioeustatic forcing on sedimentation. Occasionally, eustasy was probably outpaced by sediment yield to the basin margin in response to severe climatic conditions and/or local subsidence, such as during the glacial terminations of MIS 22 and especially MIS 20 (Massari et al., 2007). Based on the sediment accumulation rates calculated for the interglacial maxima of MIS 21 and 19 (ca. 10 and $27 \mathrm{~cm} / \mathrm{kyr}$, respectively), we estimate that the LMD lags behind the MED by ca. $5 \mathrm{kyr}$. This significant time lag is likely to reflect the strong local subsidence that persisted in creating accommodation space, and therefore deepening, well after the end of the eustatic transgression.

\section{Discussion}

Data presented in this paper yielded new and essential information on the VdM section, especially in terms of timing and duration of the main events that characterize the Early-Middle Pleistocene transition. It is held that the physical stratigraphic organization of the VdM section reflects in detail the dynamics of regional and global climates, which are validated by several proxies, such as stable oxygen isotopes, calcareous nannofossils, pollen and mollusk faunas. In particular, we accomplished an improved magnetostratigraphic documentation of the M-B geomagnetic reversal, which represents the main criterion for defining the GSSP of the Ionian Stage (Richmond, 1996; Cita et al., 2006; Head et al., 2008).

Altogether, the collected data point univocally to a continuous and undisturbed stratigraphic record of the MIS 20-MIS 18 interval, with no significant gaps or duplications. The depositional setting of the VdM section is in full agreement with the coeval stratigraphy at the Montalbano Jonico section (D'Alessandro et al., 2003; Stefanelli, 2003). However, in contrast with the latter, which is represented by a monotonous stack of hemipelagic muds ( $\mathrm{C}$ iaranfi et al., 2010), changes in the local sea level at VdM are underlined by an articulated stratigraphic architecture, which reflects the interplay between eustasy 
sediment supply and tectonics (Massari et al., 2007). This arrangement is a bonus, as it provides a robust validation of independent proxies of sea level, such as the $\delta^{18} \mathrm{O}$ of benthic foraminifers and mollusk faunas. Based on the estimated sediment accumulation rates across the M-B reversal (ca. $27 \mathrm{~cm} / \mathrm{kyr}$ ), we derived an age of 786.9 for the mid-point of the M-B polarity transition. Furthermore, our data point to a very short duration of the geomagnetic flip, in the order of 100 years or less. The age error associated to the main geomagnetic event is ca. $\pm 5 \mathrm{kyr}$, based on the inherent uncertainty of the orbital tuning method (Imbrie et al., 1984; Martinson et al., 1987). If we only consider the uncertainty in positioning the reversal $( \pm 1.5 \mathrm{~cm})$, the error is much smaller (ca. $\pm 55 \mathrm{yr}$ ).

In spite of the paleomagnetic data collected globally in the last decades from sedimentary (terrestrial and marine) and volcanic records, the age, duration and field geometry of the M-B reversal still remain controversial (see Singer, 2014; Head and Gibbard, 2015; Valet and Fournier, 2016 for a review). Our results differ from data presented from marine sediment cores by Channell et al. (2010) and Valet et al. (2014), but are consistent with many reconstructions of the dynamics of geomagnetic field reversals documented worldwide (Hyodo et al., 2006; Macrì et al., 2010; Zhao et al., 2014; Liu et al., 2014).

Moreover, our chronology is in agreement with that calculated for the Sulmona lacustrine record (Central Italy) where, based on the radiometric dating of several tephra layers, the M-B reversal yielded an age of $786.1 \pm 1.5 \mathrm{ka}$ with an estimated duration of a few decades (Sagnotti et al., 2014, 2016). It is also very close to the age of $787 \pm 1.8 \mathrm{ka}$ calculated for the North Atlantic IODP Site U-1313 core, according to the astronomical tuning of the local $\delta^{18} \mathrm{O}$ record (Expedition 306 Scientists, 2006; Ferretti et al., 2015). Notably, the VdM, Sulmona and IODP U-1313 records point to a very similar age of the M-B reversal in spite of the different approaches used to develop each of the age models (visual correlation to a regional tuning target, radiometric ages and astronomical tuning, respectively), which rule out the existence of methodologic biases.

At VdM, ChRM directions indicate that the midpoint of the M-B reversal is located in correspondence to the full MIS 19 interglacial, specifically ca. $12.5 \mathrm{~cm}$ above the base of the "Pitagora ash" (Fig. 8). The latter provides a prominent marker of the geomagnetic event, although it was not possible so far to recognize the "Pitagora ash" outside the San Mauro sub-basin. However, the (potential) lack of horizontal continuity of the "Pitagora ash" is not a concern. Since the early work of Steno (1669), it is common knowledge that sedimentary layers do not extend indefinitely, being their limits circumscribed by the shape and size of the basin where, by definition, they were deposited. Not by chance, the lateral (horizontal) physical continuity of strata is not contemplated among the guidelines for the definition of a GSSP (Remane et al., 1996). By contrast, an excellent long-distance correlation potential is demanded for the "most relevant marker events" that approximate the boundary (Remane et al., 1996). In defining the GSSP of the Ionian Stage, the "most relevant marker event" - i.e., the main guide criterion - is the M-B boundary (Richmond, 1996; Cita et al., 2006; Head et al., 2008), which can be pinpointed precisely and unambiguously in the VdM section (Fig. 8). Therefore, other than being a mere tool for stratigraphic correlation at the basin scale, the "Pitagora ash" can be employed as marker bed for assessing the stratigraphic position of the M-B boundary and, consequently, to serve as the physical reference level for defining of the GSSP of the Ionian Stage.

Furthermore, the VdM section represents one of the component segments of the composite stratigraphic succession of the Crotone Basin (Capraro et al., 2011), where the GSSP of the Calabrian Stage was defined (Vrica section; Pasini and Colalongo, 1997; Cita et al., 2012). Indeed, the stratigraphic succession exposed in the San Mauro sub-basin and neighboring areas extends well below the base of the Calabrian and, once framed in the context of the local stratigraphic succession, the VdM section can be physically linked to the Vrica section for defining the Unit Stratotype of the Calabrian Stage.

\section{Conclusions}

Data presented and discussed in this paper demonstrate that the VdM section stands out as one of the best documented records available straddling the Lower-Middle Pleistocene boundary. This assumption is based on the following evidences:

- the VdM section provides a continuous and well-documented record of the interval between late MIS 22 and full MIS 18. In particular, the section provides an excellent record of the MIS 19 interglacial, in correspondence of which the GSSP should be placed;

- the VdM section preserves a manifold, detailed and well time-constrained history of terrestrial and marine climates and sea-level across the Early-Middle Pleistocene transition;

- the VdM section holds a sharp record of the M-B geomagnetic reversal, the age of which (ca. $786.9 \mathrm{ka}$ ), obtained by tuning to the open-sea $\delta^{18} \mathrm{O}$ records, is in agreement with many records globally; - the VdM section fulfills all the requirements of Remane et al. (1996) for hosting the GSSP of the Ionian Stage (base of the Middle Pleistocene Subseries), such as a good and easily accessible exposure, continuous and expanded open-marine sedimentation, absence of synsedimentary and tectonic disturbances, abundant and diversified fossils, absence of vertical facies changes near the boundary, etc.

Hence, we deem that the GSSP of the Ionian Stage should be defined at the very base of the "Pitagora ash", i.e. $12.5 \mathrm{~cm}$ below the mid-point of the M-B magnetic reversal. We strongly believe that defining all the GSSPs of the Neogene in a consistent geographic and depositional setting - that is, the Mediterranean basin - would provide huge benefits, because correlation among contiguous sedimentary basins is more straightforward and can take advantage of a regionally-validated calibration of the main bio-magnetostratigraphic and climatic proxies.

\section{Uncited references}

Backman and Shackleton, 1983, Capraro et al., 2006, Clement, 2004, Macrì et al., 2014, Malanotte-Rizzoli and Bergamasco, 1991, Robinson et al., 1991, Steno, 1669, Suganuma et al., 2015, Tanhua et al., 2013.

\section{Acknowledgments}

This research was funded by the University of Padova (Progetto di Ateneo 2011 and ex-60\% to L. Capraro). We are grateful to Prof. D. Schreve, Editor of Quaternary Science Reviews, and two anonymous reviewers for valuable comments that greatly improved the manuscript. Thanks to C. Betto, N. Preto and C. Agnini for technical assistance. This manuscript is dedicated to Prof. Domenico Rio, who recently retired, for initiating us to the study of the $\mathrm{CB}$ and for sharing his immense scientific knowledge. His contagious enthusiasm will be missed.

\section{References}


Barone, A, Fabbri, A , Rossi, S , Sartori, R , 1982 Geological structure and evolution of the marine area adjacent to the Calabrian Arc Earth Planet Sci Lett 3, 207-221

Bensi, M, Rubino, A, Cardin, V , Hainbucher, D , ManceroMosquera, I, 2013 Structure and variability of the abyssal water masses in the Ionian Sea in the period 2003-2010 J Geophys Res 118, 1-13 http://dx doi org/10 1029/2012JC008178

Bentley, S J , Sheremet, A, Jaeger, J B , 2006 Event sedimentation, bioturbation, and preserved sedimentary fabric: field and model comparisons in three contrasting marine settings Cont Shelf Res 26, 2108-2124

Bertini, A , 2003 Early to Middle Pleistocene changes of the Italian flora and vegetation in the light of a chronostratigraphic framework Il Quat 16, 19-36

Bertini, A, Toti, F, Marino, M , Ciaranfi, N , 2015 Vegetation and climate across the early-middle Pleistocene transition at Montalbano Jonico, southern Italy Quat Int $383,74-88$

Béthoux, J, Morin, P, Madec, C, Gentill, B , 1992 Phosphorus and nitrogen behaviour in the Mediterranean sea Limnol Oceanogr 39, 1641-1654

Borzelli, G L E , Gačić, M , Cardin, V , Civitarese, G, 2009 Eastern Mediterranean transient and reversal of the Ionian sea circulation Geophys Res Lett 36, L15108 http://dx doi org/10 1029/2009GL039261

Bromley, R G , Ekdale, A A , 1984 Chondrites: a trace fossil indicator of anoxia in sediments Science 224, 872-874 http://dx doi org/10 1126/science 2244651872

Capraro, L, Asioli, A, Backman, J , Bertoldi, R, Channell, J E T , Massari, F, Rio, D , 2005 Climatic patterns revealed by pollen and oxygen isotope records across the Brunhes-Matuyama boundary in the central Mediterranean (Southern Italy) In: Head, M J , Gibbard, P L (Eds), Geol Soc Lond Spec Publ 247 Geological Society, Bath, UK, pp 159-182

Capraro, L , Consolaro, C, Fornaciari, E, Massari, F, Rio, D , 2006 Chronology of the middle-upper Pliocene succession in the Strongoli area: constraints on the geological evolution of the Crotone Basin (southern Italy) In: Moratti, G, Chalouan, A (Eds ), Tectonics of the Western Mediterranean and North Africa Geol Soc Lond Spec Publ 262 Geological Society, Bath, UK, pp 323-333

Capraro, L , Macrì, P , Scarponi, D , Rio, D , 2015 The lower to Middle Pleistocene Valle di Manche section (Calabria, Southern Italy): state of the art and current advances Quat Int 383, 36-46

Capraro, L, Massari, F , Rio, D , Fornaciari, E, Backman, J , Channell, J E T , Macrì, P , Prosser, G, Speranza, F , 2011 Chronology of the lower-middle Pleistocene succession of the south-western part of the Crotone Basin (Calabria, southern Italy) Quat Sci Rev 30, 1185-1200

Carey, S N , Sigurdsson, H , 1978 Deep-sea evidence for distribution of tephra from the mixed magma eruption of the Soufrière on St Vincent, 1902: ash turbidites and air fall Geology 6, 271-274

Castradori, D , 1993 Calcareous nannofossil biostratigraphy and biochronology in eastern Mediterranean deep-sea cores Riv Ital Paleontol S 99, 107-126

Channell, J E T , Hodell, D A , Singer, B S , Xuan, C , 2010 Reconciling astrochronological and 40Ar/39Ar ages for the Matuyama-Brunhes boundary and late Matuyama Chron Geochem Geophys Geosyst 11, Q0AA12 http://dx doi org/10 1029/2010GC003203

Ciaranfi, N , Lirer, F , Lirer, L , Lourens, L J , Maiorano, P , Marino, M , Petrosino, P , Sprovieri, M, Stefanelli, S, Brilli, M, Girone, A, Joannin, S , Pelosi, N, Vallefuoco, M , 2010 Integrated stratigraphy and astronomical tuning of lower-middle Pleistocene Montalbano Jonico section (southern Italy) Quat Int 219, 109-120

Cita, M B , Capraro, L , Ciaranfi, N , Di Stefano, E, Marino, M , Rio, D, Sprovieri, R, Vai, G B , 2006 Calabrian and Ionian: a proposal for the definition of Mediterranean stages for the lower and middle Pleistocene Episodes 29, 107-114

Cita, M B , Gibbard, P L , Head, M J , 2012 The ICS Subcommission on quaternary stratigraphy, 2012 Formal ratification of the GSSP for the base of the calabrian stage GSSP (Pleistocene series, quaternary system) Episodes 35, 388-397

Cita, M B , Podenzani, M , 1980 Destructive effects of oxygen starvation and ash falls on benthic life: a pilot study Quat Res 13, 230-241

Clifton, H E, 2006 A re-examination of facies models for clastic shorefaces Facies Models Revisited In: Posamentier, H W, Walker, R G (Eds ), Special Publication No 84 SEPM (Society for Sedimentary Geology), Tulsa, USA, pp 293-337

Coplen, T B , 1988 Normalization of oxygen and hydrogen isotope data Chem Geol Isot Geosci Sect ) 72, 293-297

Coplen, T B , 1994 Reporting of stable hydrogen, carbon, and oxygen isotopic abundances Pure Appl Chem 66, 273-276

D'Alessandro, A, La Perna, R, Ciaranfi, N, 2003 Response of macrobenthos to changes in paleoenvironments in the lower-middle Pleistocene (Lucania basin, southern Italy) Il Quat 16, 167-182

Elderfield, H, Ferretti, P, Greaves, M , Crowhurst, S J , McCave, I N , Hodell, D , Piotrowski, A, 2012 Evolution of ocean temperature and ice volume through the mid Pleistocene climate transition Science 337, 704-709 http://dx doi org/10 $1126 /$ science 1221294

Expedition 306 Scientists, 2006 Site U1313 In: Channell, J E T, Kanamatsu, T, Sato, T , Stein, R , Alvarez Zarikian, C A , Malone, M J (Eds ), The Expedition 303/306 Scientists, Proc IODP, 306 Integrated Ocean Drilling Program Management International, Inc , College Station TX http://dx doi org/10 2204/iodp proc 303306 1122006
Ferretti, P , Crowhurst, S J , Naafs, B D A, Barbante, C, 2015 The marine isotope stage 19 in the mid-latitude North Atlantic Ocean: astronomical signature and intra-interglacial variability Quat Sci Rev 108, 95-110 http://dx doi org/10 1016/ j quascirev 201410024

Flores, J A, Gersonde, R, Sierro, F J , 1999 Pleistocene fluctuations in the Agulhas current retroflection based on the calcareous plankton record Mar Micropaleontol $37,1-22$

Frew, R D , Dennis, P F , Heywood, K J , Meredith, M P , Boswell, S M , 2000 The oxygen isotope composition of water masses in the northern North Atlantic Deep Sea Res 47, 2265-2286

Gačić, M , Civitarese, G, Eusebi Borzelli, G L , Kovačević, V , Poulain, P-M , Theocharis, A, Menna, M, Catucci, A, Zarokanellos, N, 2011 On the relationship between the decadal oscillations of the northern Ionian Sea and the salinity distributions in the eastern Mediterranean J Geophys Res 116, C12002 http:// $\mathrm{dx}$ doi org/10 1029/2011JC007280

Gasparotto, G, Spadafora, E , Summa, V , Tateo, F , 2000 Contribution of grain size and compositional data from the Bengal Fan sediment to the understanding of Toba volcanic event Mar Geol 162, 561-572 http://dx doi org/10 1016/ S0025-3227(99)00090-0

Head, M J , Gibbard, P L , 2015 Early-Middle Pleistocene transitions: linking terrestrial and marine realms Quat Int 389, 7-46

Head, M J , Pillans, B , Farquhar, S , 2008 The Early-Middle Pleistocene Transition: characterization and proposed guide for the defining boundary Episodes 31, 255-259

Hemleben, C , Spindler, M , Anderson, O R , 1989 Modern Planktonic Foraminifera Springer-Verlag, New York, Berlin, Heidelberg, London, Paris, Tokyo

Hyodo, M , Biswas, D K , Noda, T , Tomioka, N, Mishima, T , Itota, C , Sato, H, 2006 Millennial- to submillennial-scale features of the Matuyama-Brunhes geomagnetic polarity transition from Osaka Bay, southwestern Japan J Geophys Res 111, B02103 http://dx doi org/10 1029/2004JB003584

Huang, T C, 1980 A volcanic sedimentation model: implications of processes and responses of deep-sea ashes Mar Geol 38, 103-122

Imbrie, J , Hays, J D , Martinson, D G , McIntyre, A , Mix, A C , Morley, J J , Pisias, N G, Prell, W L, Shackleton, N J , 1984 The orbital theory of Pleistocene climate: Support from a revised chronology of the marine $\mathrm{d} 18 \mathrm{O}$ record In: Berger, A L, et al (Eds ), Milankovitch and Climate, Part 1 Reidel, The Netherlands, pp 269-305

Istituto Nazionale di Geofisica e Vulcanologia, 2007 Italian magnetic network and geomagnetic field maps of Italy at year 20050 Boll Geod Sci affini, anno LXVI 1

Kazaoka, O , Suganuma, Y , Okada, M , Kameo, K, Head, M J , Yoshida, T , Sugaya, M, Kameyama, S , Ogitsu, I, Nirei, H , Aida, N , Kumai, H, 2015 Stratigraphy of the Kazusa group, boso peninsula: an expanded and highly-resolved marine sedimentary record from the lower and middle Pleistocene of central Japan Quat Int $383,116-135$

Kirschvink, J L , 1980 The least-squares line and plane and the analysis of palaeomagnetic data Geophys J R Astr Soc 62, 699-718

Lascaratos, A, Williams, R G, Tragou, E, 1993 A mixed-layer study of the formation of Levantine Intermediate Water J Geophys Res 98, 14739-14749

Le Maitre, R W , 2002 Igneous rocks A Classification and Glossary of Terms Recommendations of the International Union of Geological Sciences Subcommission on the Systematics of Igneous Rocks Cambridge University Press, Cambridge, New York, Melbourne, 236

Liu, J , Shi, X, Liu, Q, Ge, S , Liu, Y, Yao, Z, Zhao, Q, Jin, C , Jiang, Z, Liu, S, Qiao, S , Li, X , Li, C , Wang, C , 2014 Magnetostratigraphy of a greigite-bearing core from the South Yellow Sea: implications for remagnetization and sedimentation J Geophys Res Solid Earth 119, 7425-7441 http://dx doi org/10 1002/ 2014JB011206

Lisiecki, L E , Raymo, M E , 2005 A Plio-Pleistocene stack of 57 globally distributed benthic $\delta^{18} \mathrm{O}$ records Paleoceanography 20, PA1003 http://dx doi org/10 1029/ 2004PA001071

Lourens, L J , 2004 Revised tuning of Ocean Drilling Program Site 964 and KC01B (Mediterranean) and implications for the $\delta^{18} \mathrm{O}$, tephra, calcareous nannofossil, and geomagnetic reversal chronologies of the past $11 \mathrm{Myr}$ Paleoceanography 19, PA3010 http://dx doi org/10 1029/2003PA000997

Lowe, D R , 1982 Sediment gravity flows: II Depositional models with special reference to the deposits of high density turbidity currents J Sediment Res 52, 279-297

Macrì, P , Speranza, F , Capraro, L , 2014 Magnetic fabric of Plio-Pleistocene sediments from the Crotone fore-arc basin: insights on the recent tectonic evolution of the Calabrian Arc (Italy) J Geodyn 81, 67-79

Maiorano, P , Marino, M , 2004 Calcareous nannofossil bioevents and environmental control on temporal and spatial patterns at the Early-Middle Pleistocene Mar Micropaleontol 53, 405-422

Malanotte-Rizzoli, P , Hecht, A, 1988 Large scale properties of the Eastern Mediterranean: a review Oceanol Acta 11,323-335

Malanotte-Rizzoli, P , Artale, V , Borzelli-Eusebi, G L , Brenner, S , Crise, A, Gačić, M, Kress, N , Marullo, S , Ribera d'Alcalà, M, Sofianos, S, Tanhua, T Theocharis, A, Alvarez, M , Ashkenazy, Y, Bergamasco, A, Cardin, V, Carniel, S , Civitarese, G, D'Ortenzio, F , Font, J , Garcia-Ladona, E, Garcia-Lafuente, 
J M , Gogou, A , Gregoire, M, Hainbucher, D , Kontoyannis, H , Kovacevic, V, Kraskapoulou, E, Kroskos, G, Incarbona, A, Mazzocchi, M G, Orlic, M , Ozsoy, E , Pascual, A, Poulain, P M , Roether, W , Rubino, A, Schroeder, K, Siokou-Frangou, J, Souvermezoglou, E, Sprovieri, M, Tintoré, J , Triantafyllou, G, 2014 Physical forcing and physical/biochemical variability of the Mediterranean Sea: a review of unresolved issues and directions for future research Ocean Sci 10, 281-322

Malanotte-Rizzoli, P , Manca, B B , Ribera d'Acala, M , Theocharis, A , Bergamasco, A, Bregant, D , Budillon, G, Civitarese, G, Georgopoulos, D, Michelato, A, Sansone, E, Scarazzato, P, Souverrmezoglou, E, 1997 A synthesis of the Ionian hydrography, circulation and water mass pathways during POEM-Phase I Prog Oceanogr 39, 153-204

Malanotte-Rizzoli, P, Manca, B B , Ribera d'Alcalà, M, Theocharis, A, Brenner, A , Budillon, G, Ozsoy, E, 1999 The Eastern Mediterranean in the 80s and in the 90s: the big transition in the intermediate and deep circulations Dyn Atmos Oceans 29, 365-395

Marquez, E J , 2000 The 1991 Mount Pinatubo eruption and Eastern South China Sea foraminifera: occurrence, composition and recovery Isl Arc 9, 527-541

Martinson, D G, Pisias, N G , Hays, J D , Imbrie, J, Moore, T C, Shackleton, N J , 1987 Age dating and the orbital theory of the Ice Ages: development of a high-resolution 0 to 300,000-year chronostratigraphy Quat Res 27,1-29

Massari, F , Capraro, L , Rio, D , 2007 Climatic modulation of timing of systems-trac development with respect to sea-level changes (middle Pleistocene of Crotone, Calabria, Southern Italy) J Sediment Res 77, 461-468

Massari, F , Rio, D , Sgavetti, M , Prosser, G, D'Alessandro, A , Asioli, A , Capraro, L, Fornaciari, E, Tateo, F , 2002 Interplay between tectonics and glacio-eustasy: Pleistocene succession of the Crotone Basin, Calabria (southern Italy) Geol Soc Am Bull 114, 1183-1209

Massari, F, Sgavetti, M , Rio, D , D'Alessandro, A , Prosser, G, 1999 Sedimentary record of falling stages of Pleistocene glacio-eustatic cycles in shelf setting (Crotone Basin, south Italy) Sediment Geol 127, 85-110

Massari, F, Prosser, G, Capraro, L , Fornaciari, E , Consolaro, C, 2010 A revision of the stratigraphy and geology of the south-western part of the Crotone basin (Southern Italy) Ital J Geosci 129, 353-384

Manville, V, Wilson, C J N , 2004 Vertical density currents: a review of their potential role in the deposition and interpretation of deep-sea ash beds $\mathrm{J}$ Geol Soc Lond 161,947-958

Manville, V , Németh, K, Kano, K, 2009 Source to sink: a review of three decades of progress in the understanding of volcaniclastic processes, deposits, and hazards Sediment Geol 220, 136-161

Melinte, M C , 2005 Calcareous nannoplankton, a tool to assign environmental changes Geo-Eco-Marina 7-8, 136-143

Mezzetti, R , Morandi, N , Tateo, F , Dondi, M , 1991 Il contributo vulcanoderivato in successioni pelitiche oligomioceniche dell'Appennino settentrionale $\mathrm{G}$ Geol 53, 167-185

Noirfalise, A, Dahl, E, Ozenda, P, Quezél, P , Bohn, W , Trautmann, W, Wagner, H, Rivas-Martinez, S, Rameau, J C , Mavrommatis, G, Einarsson, E, Gentile, S , Tomaselli, R, Kalkhoven, J T R, Malato-Beliz, J, Newbold, C , Pahlsson, L Baum, P , Ribaut, J P , Cornaert, M H , 1987 Carte de la vegetation naturelle des Etats membres des Communautés européennes et du Conseil de l'Europe Office des publications des Communautés européennes, Luxembourg

Pasini, G, Colalongo, M L , 1997 The Pliocene-Pleistocene boundary stratotype at Vrica, Italy In: Van Couvering, J (Ed ), The Pleistocene Boundary and the Beginning of the Quaternary Cambridge University Press, Cambridge, U K, p 1545

Pasini, G, Selli, R, 1977 The section of Le Castella Giorn Geol 41, 424-430

Pasini, G, Selli, R, Tampieri, R, Colalongo, M L , D'Onofrio, S , Borsetti, A M , Cati, F, 1975 The Vrica section In: Pasini, G (Ed ), The Neogene-quaternary Boundary: II Simposio (Bologna-crotone), Excursion Guide-book Editografica Rastignano, Bologna, pp 62-72

Petrosino, P , Jicha, B R , Mazzeo, F C , Ciaranfi, N , Girone, A, Maiorano, P , Marino, M , 2015 The Montalbano Jonico marine succession: an archive for distal tephra layers at the Early-Middle Pleistocene boundary in southern Italy Quat Int 383,89-103

Pierre, C, 1999 The oxygen and carbon isotope distribution in the Mediterranean water masses Mar Geol 153, 41-55

Pillans, B , 2003 Subdividing the Pleistocene using the Matuyama-brunhes boundary (MBB): an Australasian perspective Quat Sci Rev 22, 1569-1577

Pillans, B , Gibbard, P L , 2012 Chapter 30: the quaternary period In: Gradstein, F M , Ogg, J , Schmitz, M, Ogg, G (Eds ), The Geologic Time Scale 2012 Elsevier, Amsterdam, pp 980-1010

Pujol, C, Vergnaud-Grazzini, C , 1995 Distribution patterns of live planktonic foraminifera as related to regional hydrography and productive systems of the Mediterranean Sea Mar Micropaleontol 25, 187-217

Raffi, I, Backman, J , Fornaciari, E, Pälike, H , Rio, D , Lourens, L , Hilgen, F , 2006 A review of calcareous nannofossil astrobiochronology encompassing the past 25 million years Quat Sci Rev 25, 3113-3137

Remane, J, Bassett, M G, Cowie, J W , Gohrbandt, K H, Lane, H R , Michelsen, O, Wang, N, 1996 Revised guidelines for the establishment of global chronostratigraphic standards by the International Commission on Stratigraphy (ICS) Episodes 19,77-81
Richmond, G M , 1996 The INQUA-approved provisional Lower-Middle Pleistocene boundary In: Turner, C (Ed), The Early-middle Pleistocene in Europe Balkema, Rotterdam, pp 319-326

Rio, D , 1982 The fossil distribution of Coccolithophore Genus Gephyrocapsa Kamptner and related Plio-Pleistocene chronostratigraphic problems In: In: Prell, W L , Gardner, J V , et al (Eds ), Proceedings of the Deep Sea Drilling Project, Initial Reports vol 68 US Government Printing Office, Washington, DC, pp 325-343 Deep Sea Drilling Project

Rio, D, Channell, J E T , Massari, F, Poli, M S , Sgavetti, M , D'Alessandro, A, Prosser, G, 1996 Reading Pleistocene eustasy in a tectonically active siliciclastic shelf setting (Crotone peninsula, Southern Italy) Geology 24, 743-746

Rio, D, Sprovieri, R, Di Stefano, E, 1998 The Gelasian Stage (Upper Pliocene): a new unit for the global standard chronostratigraphic scale Episodes 21, 82-87

Roda, C , 1964 Distribuzione e facies dei sedimenti Neogenici del Bacino Crotonese Geol Rom 3, 319-366

Rossi, S, Sartori, R, 1981 A seismic reflection study of the external Calabrian Arc in the northern Ionian Sea (eastern Mediterranean) Mar Geophys Res 4, 403-426

Sagnotti, L, Scardia, G, Giaccio, B , Liddicoat, J C, Nomade, S , Renne, P R, Sprain, C J , 2014 Extremely rapid directional change during Matuyama-Brunhes geomagnetic polarity reversal Geophys J Int 199, 1110-1124

Sagnotti, L, Renne, P R, Giaccio, B , Scardia, G, Liddicoat, J C, Sprain, C J , Nomade, S , 2016 How fast was the Matuyama-Brunhes geomagnetic reversal? A new subcentennial record from the Sulmona Basin, central Italy Geophys J Int $204,798-812$

Scarponi, D , Huntley, J W , Capraro, L , Raffi, S , 2014 Stratigraphic paleoecology of the S Mauro Marchesato section (Crotone Basin, Italy): a candidate GSSP of the middle Pleistocene Palaeogeogr Palaeoclimatol Palaeoecol 402, 30-43

Shackleton, N J , 1967 Oxygen isotope analyses and Pleistocene temperatures re-assessed Nature 215, 15-17

Shackleton, N J , 1974 Attainment of isotopic equilibrium between ocean water and the isotopic equilibrium of the benthonic foraminifera genus Uvigerina: isotopic changes in the ocean during the last glacial Les methods quantitatives d'etude des variations du climat au cours du Pleistocene, Gif-sur-Yvette Colloq Int Du CNRS 219, 203-210

Shackleton, N J , Berger, A, Peltier, W R , 1990 An alternative astronomical calibration of the lower Pleistocene timescale based on ODP Site 677 Trans R Soc Edinb Earth Sci 81, 251-261

Simon, Q, Bourlès, D L, Bassinot, F , Nomade, S , Marino, M , Ciaranfi, N , Girone, A, Maiorano, P, Thouveny, N , Choy, S , Dewilde, F, Scao, V , Isguder, G, Blamart, D , 2016 Authigenic ${ }^{10} \mathrm{Be} /{ }^{9} \mathrm{Be}$ ratio signature of the Matuyama-Brunhes boundary in the Montalbano Jonico marine succession Earth Plan Sci Lett 460, 255-267 http://dx doi org/10 1016/j epsl 201611052

Singer, B S , 2014 A Quaternary geomagnetic instability time scale Quat Geochron 21, 29-52

Sparks, R S J , Brazier, S , Huang, T C, Muerdter, D , 1983 Sedimentology of the minoan deep-sea tephra layer in the Aegean and eastern Mediterranean Mar Geol 54, 131-167

Speranza, F , Macrì, P , Rio, D , Fornaciari, E , Consolaro, C , 2011 Palaeomagnetic evidence for a post-1 2 Ma disruption of the Calabria terrane: consequences of slab breakoff on orogenic wedge tectonics Geol Soc Am Bull 123, 925-933 http:// $\mathrm{dx}$ doi org/10 1130/B30214 1

Sprovieri, R, Di Stefano, E, Howell, M, Sakamoto, T, Di Stefano, A, Marino, M, 1998 Integrated calcareous plankton biostratigraphy and cyclostratigraphy at Site 964 In: In: Robertson, A H F , Emeis, K C , Richter, C, Camerlenghi, A (Eds), Proceedings Ocean Drilling Program, Scientific Results vol 160 Ocean Drilling Program, College Station, TX, pp 155-165

Sprovieri, R, Di Stefano, E, Incarbona, A, Gargano, M E, 2003 A high-resolution record of the last deglaciation in the Sicily channel based on foraminifera and calcareous nannofossil quantitative distribution Palaeogeogr Palaeoclimatol Palaeoecol 202, 119-142

Stefanelli, S , 2003 Benthic foraminiferal assemblages as tools for paleoenvironmenta reconstruction of the early-middle Pleistocene Montalbano Jonico composite section B Soc Paleontol Ital 42, 281-299

Steno, N , 1669 De Solido Intra Solidum Naturaliter Contento Dissertationis Prodromus Stella, Florence

Thierstein, H R , Geitzenauer, K, Molfino, B , Shackleton, N J , 1977 Global synchroneity of late Pleistocene coccolith datum levels; validation by oxygen isotopes Geology 5, 400-404

Valet, J -P , Bassinot, F, Bouilloux, A, Bourlès, D , Nomade, S, Guillou, V , Lopes, F , Thouveny, N, Dewilde, F , 2014 Geomagnetic, cosmogenic and climatic changes across the last geomagnetic reversal from equatorial Indian Ocean sediments Earth Planet Sci Lett 397, 67-79

Valet, J -P , Fournier, A, 2016 Deciphering records of geomagnetic reversals Rev Geophys 54, 410-446 http://dx doi org/10 1002/2015RG000506

Van Dijk, J P , Okkes, M , 1991 Neogene tectonostratigraphy and kinematics of Calabrian basins; implications for the geodynamics of the Central Mediterranean Tectonophysics 196, 23-60 
Vergnaud-Grazzini, C, Devaux, M , Znaidi, J , 1986 Stable isotope "anomalies" in the Mediterranean Pleistocene records Mar Micropaleontol 10, 35-69

Villa, G, Palandri, S, Wise, S W , 2005 Quaternary calcareous nannofossils from Periantarctic basins: Paleoecological and paleoclimatic implications Mar Micropaleontol 56, 103-121

Wang, P, Tian, J , Lourens, L J , 2010 Obscuring of long eccentricity cyclicity in Pleistocene oceanic carbon isotope records Earth Planet Sci Lett 290,319-330

Wells, P , Okada, H , 1996 Holocene and Pleistocene glacial palaeoceanography off southeastern Australia, based on foraminifers and nannofossils in Vema cored hole V18-222 Aust J Earth Sci 43, 509-523

Wells, P , Okada, H , 1997 Response of nannoplankton to major changes in sea-surface temperature and movements of hydrological fronts over Site DSDP 594
(South Chatham Rise, southeastern New Zealand), during the last 130 kyr Mar Micropaleontol 32, 341-363

Wheatcroft, R A, 1990 Preservation potential of sedimentary event layers Geology $18,843-845$

Wüst, G , 1961 On the vertical circulation of the Mediterranean Sea J Geophys Res 66, 3261-3271

Zhao, H, Qiang, X, Sun, Y, 2014 Apparent timing and duration of the Matuyama-Brunhes geomagnetic reversal in Chinese loess Geochem Geophys Geosyst 15, 4468-4480 http://dx doi org/10 1002/2014GC005497 